Article

\title{
Interaction of Halictine-Related Antimicrobial Peptides with Membrane Models
}

\author{
Markéta Pazderková ${ }^{1,2}{ }^{1}$, Petr Maloň ${ }^{1} \oplus$, Vlastimil Zíma ${ }^{1}$, Kateřina Hofbauerová ${ }^{1}{ }^{\oplus}$, \\ Vladimír Kopecký Jr. ${ }^{1}{ }^{1}$, Eva Kočišová ${ }^{1}{ }^{\circledR}$, Tomáš Pazderka ${ }^{1}$, Václav Čeřovský ${ }^{2}{ }^{\circledR}$ and \\ Lucie Bednárová 2,*(D) \\ 1 Institute of Physics, Faculty of Mathematics and Physics, Charles University, Ke Karlovu 5, \\ 12116 Prague 2, Czech Republic; pazderkova@karlov.mff.cuni.cz (M.P.); malonp@karlov.mff.cuni.cz (P.M.); \\ vlastimil.zima@gmail.com (V.Z.); hofbauer@karlov.mff.cuni.cz (K.H.); kopecky@karlov.mff.cuni.cz (V.K.J.); \\ kocisova@karlov.mff.cuni.cz (E.K.); tomas.pazderka@matfyz.cz (T.P.) \\ 2 Institute of Organic Chemistry and Biochemistry, v.v.i., Academy of Sciences of the Czech Republic, \\ Flemingovo náměstí 2, 16610 Prague 6, Czech Republic; cerovsky@uochb.cas.cz \\ * Correspondence: bednarova@uochb.cas.cz; Tel.: +420-220-183-593; Fax: +420-224-310-177
}

Received: 27 December 2018; Accepted: 28 January 2019; Published: 1 February 2019

check for updates

\begin{abstract}
We have investigated structural changes of peptides related to antimicrobial peptide Halictine-1 (HAL-1) induced by interaction with various membrane-mimicking models with the aim to identify a mechanism of the peptide mode of action and to find a correlation between changes of primary/secondary structure and biological activity. Modifications in the HAL-1 amino acid sequence at particular positions, causing an increase of amphipathicity (Arg/Lys exchange), restricted mobility (insertion of Pro) and consequent changes in antimicrobial and hemolytic activity, led to different behavior towards model membranes. Secondary structure changes induced by peptide-membrane interaction were studied by circular dichroism, infrared spectroscopy, and fluorescence spectroscopy. The experimental results were complemented by molecular dynamics calculations. An $\alpha$-helical structure has been found to be necessary but not completely sufficient for the HAL-1 peptides antimicrobial action. The role of alternative conformations (such as $\beta$-sheet, PPII or $3_{10}$-helix) also seems to be important. A mechanism of the peptide mode of action probably involves formation of peptide assemblies (possibly membrane pores), which disrupt bacterial membrane and, consequently, allow membrane penetration.
\end{abstract}

Keywords: antibacterial peptides; halictine; circular dichroism; fluorescence; infrared spectroscopy

\section{Introduction}

Antimicrobial peptides (AMPs) are important participants in the initial response of immune systems and have been found in nearly all living organisms including bacteria, fungi, plants and animals [1-4]. Potentially, they offer alternatives to disease treatment as a replacement for common antibiotics, without disadvantages like resistance, allergies, etc. Many AMPs have been isolated and subsequently synthesized together with their analogs. Their antibacterial activities have been determined against Gram-negative and Gram-positive bacteria as well as against cancer cells [1,5-8]. A general lack of new antibiotics for the treatment of Gram-negative infections and a continuous increase in multi-drug resistance has recently caused a wave of interest in possible mechanisms of AMP action. One of the recognized effects is their ability to disrupt bacterial membranes via non-specific electrostatic interactions with the membrane lipid components [1]. There are two recognized common and important criteria for functionally active AMPs. These include a network of cationic charges and the ability to adopt an amphipathic structure, where hydrophobic and hydrophilic 
parts form oppositely oriented domains upon interaction with negatively charged bacterial membranes. The possible mechanisms of AMP action fall into two basic categories: (1) formation of pores in bacterial membranes via transmembrane penetration (e.g., the barrel stave and toroidal pore models) or (2) disruption of membranes (e.g., the carpet and detergent models) [1,8-11]. These then lead to the breakdown of the transmembrane potential causing leakage of the cell contents and finally cell death. The physico-chemical concept of such antibacterial action has been discussed and particular attention has been paid to changes of the phase state of the membrane [12-14].

Quite importantly, AMPs exhibit high preference for bacterial over mammalian cells. This is probably associated with known significant differences between mammalian and bacterial cell membranes $[5,6,12,15,16]$. The type of mammalian cell membrane is represented by the plasma membrane of red blood cells. This membrane consists of about $60 \%$ phospholipids and $25 \%$ cholesterol. Distribution of phospholipids between outer and inner lipid leaflets of the bilayer is asymmetric with neutral phospholipids phosphatidylcholine and sphingomyelin exposed to the extracellular matrix. On the other hand, negatively charged lipids such as phosphatidylglycerol, diphosphatidylglycerol or cardiolipin and the zwitterionic phosphatidylethanolamine are the main constituents of the cytoplasmic membrane of both Gram-positive and Gram-negative bacteria (having an additional layer of peptidoglycan and an outer membrane layer composed mainly of lipopolysaccharides). In a simplified way, the AMPs are exposed to a neutral membrane surface in the case of mammalian cells and to a negatively charged surface in the case of bacteria.

Within the last decade, several original discoveries of AMPs isolated from the venom of Hymenoptera insects have been made and described by our collaborators [17-22]. Biological activities of these new AMPs have been determined and compared to the activities of their synthesized analogs to consider their eventual pharmacological application. Based on initial electronic circular dichroism (ECD) investigations, the peptides may undergo substantial structural changes in the presence of simple membrane-mimicking models such as 2,2,2-trifluoroethanol (TFE) and sodium dodecyl sulfate (SDS). Moreover, peptide structural behavior can be substantially affected by primary structure modifications. In our initial study of peptides related to Halictine-1 (HAL-1), a short linear AMP containing 12 amino acids isolated from the venom of the eusocial bee Halictus sexcinctus, we demonstrated that HAL-1 and its analogs are able to form amphipathic structures when in $\alpha$-helical conformation [19]. A subsequent detailed spectroscopic study of the natural HAL-1 [23] resulted in a nontrivial picture involving not only a significant role of $\alpha$-helical conformation but also an important role of other arrangements including random coil, $\beta$-structure and/or polyproline II (PPII) structures. Overall, the results presented overwhelming complexity and implied a need for additional, more detailed studies. Here, we focus in detail on physico-chemical properties and structure-activity relations of peptides related to HAL-1 including their geometries, conformation and dynamic behavior in various situations like in solutions, or in interaction with different membrane models. Conformational changes have been induced by an interaction with (a) TFE-an $\alpha$-helix forming solvent [24], (b) SDS micelles-a very simple bacterial membrane model $[25,26]$ and also by (c) liposomes of different phospholipid composition presented by a combination of various concentration mixtures of 1,2-dimyristoyl-sn-glycerol-3-phosphatidylcholine (PC) and 1,2-dimyristoyl-sn-glycero-3-phospho-(1'-rac-glycerol) (PG)—systems more accurately mimicking mammalian and bacterial membranes [25,26].

Inspired by the already presented analogues with specific sequence modifications and their known biological activities [19], here, we present a study of HAL-1 analogs (Table 1) with possible therapeutic potential (i.e., the analogs exhibiting potent activities against various pathogens while having substantially reduced hemolytic activity against red blood cells). Particularly, HAL-1/10 and HAL-1/20 analogs look promising for potential therapeutic applications because these peptides lack undesired hemolytic activities, while their antibacterial potencies, especially against $P$. aeruginosa, are higher than for natural HAL-1. A combined use of infrared (IR), circular dichroism (electronic (ECD) and vibrational (VCD)) and fluorescence spectroscopies allows us to obtain complex information about 
structural changes of the peptides upon interaction with model membranes. The set of IR, ECD, and fluorescence spectroscopy experiments performed at room temperature is complemented by time- and temperature-dependent ECD measurements, which allows us to distinguish and describe even subtle conformational changes of the peptides in interaction with membrane-mimicking environments, and by ECD and VCD study of a concentration dependency of HAL-1 analogs. Utilization of these experimental methods might help us to better understand the relation between the peptide primary/secondary structure changes and elucidate the mechanisms of the HAL-1 peptides action. A correlation between the peptide structural changes and biological activities can be also determined. The experimental data are compared to molecular dynamics (MD) simulations of HAL-1 in interaction with model membranes.

Table 1. Amino acid sequences, physico-chemical and biological properties $\left(\mu_{\mathrm{H}}\right.$ is the hydrophobic moment, and $H$ represents the mean hydrophobicity, calculated according to [27]), of the studied antibacterial HAL-1 peptides. Data were taken from ref. [19]. Point mutations with respect to the natural HAL-1 peptide are underlined. The Schiffer-Edmundson wheel projection of the HAL-1 and its analogs is depicted below the table.

\begin{tabular}{|c|c|c|c|c|c|c|c|c|c|c|}
\hline \multirow{2}{*}{ Acronym } & \multirow{2}{*}{ Sequence } & \multirow{2}{*}{ MW (Da) } & \multirow{2}{*}{ Charge } & \multirow{2}{*}{$\mu_{\mathrm{H}}$} & \multirow{2}{*}{$H$} & \multicolumn{4}{|c|}{ Antimicrobial Activity MIC $(\mu \mathrm{M})$} & \multirow{2}{*}{$\begin{array}{l}\text { Hemolytic } \\
\text { LC }_{50}(\mu \mathrm{M})\end{array}$} \\
\hline & & & & & & B. $^{1}$ & $\mathrm{~S}^{2}$ & E. $^{3}$ & $\mathbf{P}^{4}$ & \\
\hline HAL-1 & GMWSKILG & 1408.9 & +3 & 0.380 & -0.004 & 0.8 & 7.7 & 3.8 & 45.0 & 82 \\
\hline HAL-1/2 & GMWSKILGPLIR & 1368.8 & +3 & 0.361 & +0.023 & 3.6 & $>100$ & 30.0 & $>100$ & $>200$ \\
\hline HAL-1/6 & GMWSKILGHLIK & 1380.6 & +3 & 0.323 & +0.051 & 1.3 & 15.8 & 7.2 & 65.0 & 132 \\
\hline HAL-1/10 & GMWKKILGKLLIR & 1440.9 & +5 & 0.416 & -0.133 & 0.8 & 15.0 & 2.3 & 13.1 & $>200$ \\
\hline HAL-1/20 & GKWSKILGKLLIR & 1396.9 & +5 & 0.473 & -0.176 & 1.7 & 21.7 & 2.3 & 28.3. & $>200$ \\
\hline
\end{tabular}

${ }^{1}$ Bacillus subtilis, ${ }^{2}$ Staphylococcus aureus, ${ }^{3}$ Escherichia coli, ${ }^{4}$ Pseudomonas aeruginosa.

\section{Results and Discussion}

In our study, we investigate effects of changes in ionicity, hydrophobicity, flexibility and/or amphipathicity of the chosen peptides induced by an exchange of selected residues by Lys and Pro residues (see Table 1) on their structural behavior in membrane-mimicking environments represented by TFE, SDS micelles and phosphatidylcholine/phosphatidylglycerol-based liposomes. Based on the simple peptide structural prediction [28], the substitution of amino acids Ser4 and His9 (HAL-1/10), Met2 and His9 (HAL-1/20) or Arg12 (HAL-1/6) by Lys stabilizes the $\alpha$-helical conformation, and the replacement of two amino acids by Lys (HAL-1/10 and HAL-1/20) improves the helical amphipathicity of the peptides (see Table 1). On the contrary, insertion of Pro9 (HAL-1/2) may cause structural irregularity, as Pro often breaks regular structures.

\subsection{Structural Changes Followed by ECD}

\subsubsection{Structural Changes Due to the Presence of TFE and SDS}

Native HAL-1 in the aqueous environment, as well as all HAL-1 analogs, show a predominantly unordered structure, characterized by a negative ECD band at $198 \mathrm{~nm}$ [29] (Figure 1). Upon addition of TFE, ECD spectra undergo a shape change. Formation of double negative minima at 205 and $222 \mathrm{~nm}$ indicates a gradual appearance of an $\alpha$-helical component (an isodichroic point at $202 \mathrm{~nm}$ suggests a two-state conformational change) (not shown). According to the two-state model [30] (Table A1), 
the presence of 30\% TFE $(v / v)$ causes a $~ 20-30 \%$ increase in the $\alpha$-helical content, depending slightly on the particular primary structure. In the presence of SDS, the spectral changes appear more complex (Figure 1). The process conditioned by SDS is contributed not only by unordered and $\alpha$-helical conformations, but also by secondary structures like a $\beta$-sheet or PPII helix [31]. Interaction with various proportions of SDS occurs in several stages, and a simple process of the two-state equilibrium does not describe sufficiently all the observed structural changes (Tables A1 and A2). At low concentrations (less than $2 \mathrm{mM}$, i.e., below critical micelle concentration (cmc)) SDS causes an intensity decrease of ECD curves. In the case of HAL-1/6 (Arg12 replaced by Lys), this process causes even a sign flip. At low concentrations SDS does not act as a membrane model but serves as a denaturation agent [32], thus the ECD curves under such conditions offer two possible explanations: either the original unordered/PPII structure adopts a conformation with a higher $\beta$-sheet content, or it becomes a truly statistical random conformation due to an interaction with SDS molecules. These two structures can hardly be distinguished on the basis of ECD. Rather different spectral behavior is observed for the analog HAL-1/20, for which the formation of a positive band at $194 \mathrm{~nm}$ and negative bands at 208 and $222 \mathrm{~nm}$ typical for $\alpha$-helical conformation is observed even for $0.16 \mathrm{mM}$ SDS concentration (i.e., far below cmc). Moreover, the ECD bands at 194 and $222 \mathrm{~nm}$ exhibit, under these conditions, the highest spectral intensities. Formation of the $\alpha$-helical conformation for HAL-1/20 below $\mathrm{cmc}$ could be due to the substitution of Met2 by Lys which favors interaction with anionic SDS molecules and increases the peptide polarity and amphipathicity (see Table 1) [27]. For all the analogs except for HAL-1/20, with the increase of SDS concentration above cmc (i.e., when SDS starts acting as a crude membrane model) [33], we observe a pronounced increase of the $\alpha$-helical content (formation of negative maxima at 208 and $222 \mathrm{~nm}$ and an increase of overall spectral intensity; Figure 1). For these peptides, additional spectral changes appear with a further increase of SDS concentration above $8 \mathrm{mM}$. At first the negative maximum at $208 \mathrm{~nm}$ shifts to $205 \mathrm{~nm}$ with the preserved band intensity, and the intensity of the negative maximum at $222 \mathrm{~nm}$ discernibly decreases. Then, an overall ECD intensity decreases and the maxima at $205 \mathrm{~nm}$ and $222 \mathrm{~nm}$ shift to $206 \mathrm{~nm}$ and $219 \mathrm{~nm}$, respectively. This could be due to an additional formation of $3_{10}$-helix, PPII or $\beta$-structure [34]. For HAL-1/20 such spectral changes are observed for SDS concentration above 4 mM SDS.

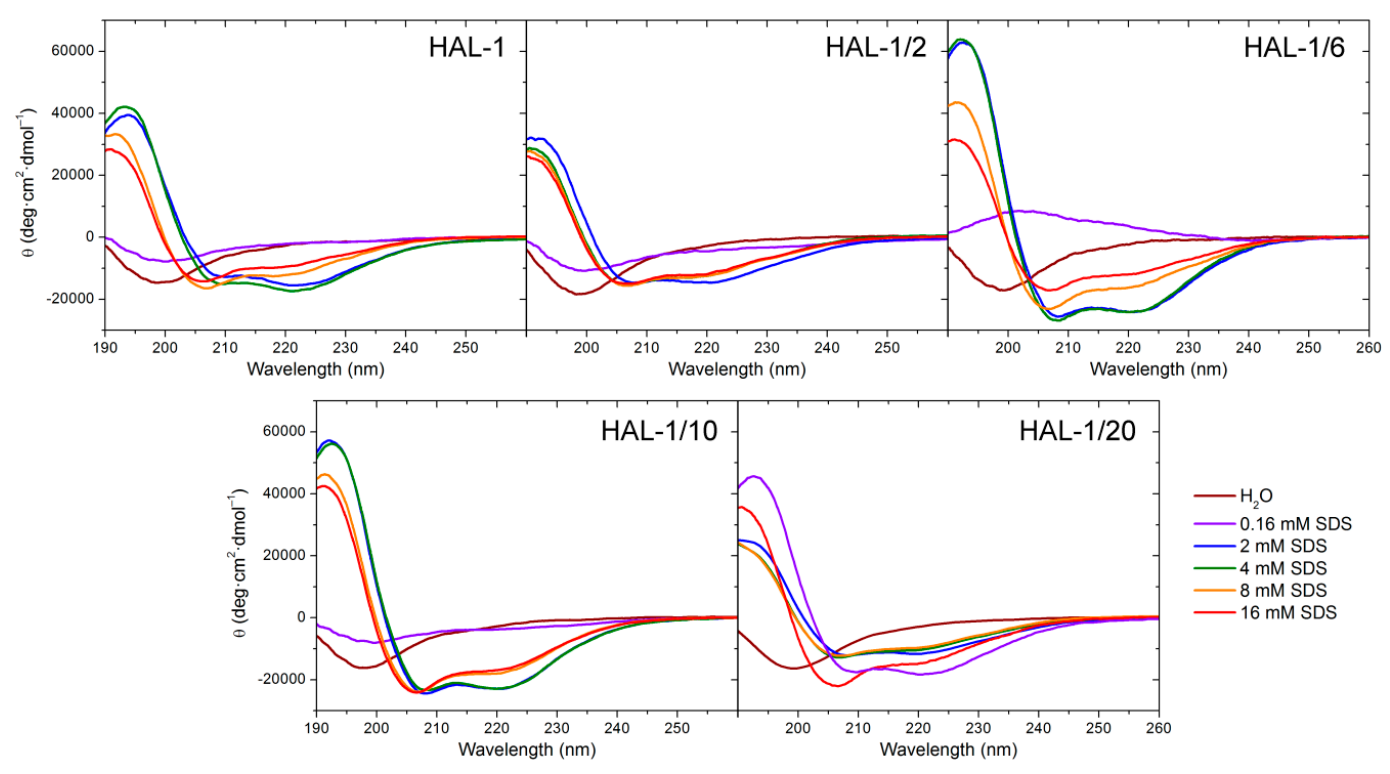

Figure 1. ECD spectra of HAL-1 and its analogs $(0.125 \mathrm{mg} / \mathrm{mL})$ in aqueous solution and in the presence of $\operatorname{SDS}(0.16,2,4,8$, and $16 \mathrm{mM})$.

The numerical ECD analysis confirms these qualitative findings (Table A1). As for HAL-1, for HAL-1/ 6 and HAL-1/10 the maximal $\alpha$-helical content is achieved in 2 mM SDS while for HAL-1/20, 
it is maximal in $0.16 \mathrm{mM}$ SDS. For SDS concentration above $4 \mathrm{mM}$, numerical analysis indicates a slight decrease of the $\alpha$-helical and unordered structure content and a subtle increase of $\beta$-structures ( $\beta$-sheet and $\beta$-turn) for all the peptides except for HAL-1/20. For 16 mM SDS, the $\alpha$-helical structure still dominates at the expense of other structures (Table A2). As expected, the substitution of His 9 by Pro in HAL-1/ 2 decreases the ability of the peptide to form an $\alpha$-helix (the $\alpha$-helical fraction does not exceed $50 \%$ ). However, the numerical ECD data analysis, even with included PPII and the $3_{10}$-helical structure, can provide only a rough estimation of observed spectral changes depending on the available reference set [35-38].

We have previously suggested that, for natural HAL-1, additional spectral changes in the presence of SDS could originate in an alternation of the PPII structure content [23]. In order to recognize the PPII structure in ECD spectra of HAL-1 analogs in SDS solution, we have combined differential ECD spectra with ECD spectra of the thermal denaturation (Figures 2 and 3) [31,39,40]. For all the studied peptides, differential ECD spectra indicate that a temporary increase of the $\alpha$-helical content is followed by an additional structural reorganization-probably either a PPII structure formation or a decrease of a $\beta$-sheet content characterized by a positive band at $\sim 225 \mathrm{~nm}$, whose intensity increases with increasing SDS concentration (Figure 2). HAL-1/2 undergoes these changes only moderately, probably due to the presence of Pro residue, which may cause conformational stiffness. The temperature-dependent ECD spectra of HAL-1 analogs exhibit similar features. At low temperature $\left(5^{\circ} \mathrm{C}\right)$ they show the negative band at $\sim 199 \mathrm{~nm}$ and the weaker positive band at $220 \mathrm{~nm}$ (Figure 3). With a temperature increase, both of these bands decrease in intensity. An isodichroic point at $210 \mathrm{~nm}$ indicates a two-state transition with decreasing PPII structure content [31,39]. At low temperature $\left(5^{\circ} \mathrm{C}\right)$, distinct spectral intensities of the analogs' ECD curves indicate differences in peptide structural arrangement. While HAL-1/10 seems to have the highest portion of PPII structure and higher flexibility, HAL-1/20 appears to possess the highest fraction of unordered structure and less flexibility in its arrangement. Principal component analysis (PCA) indicates that thermal denaturation of the peptides probably leads to an increase of the $\beta$-structure content at the expense of decreasing percentage of unordered and/or PPII conformations [39] (Figure A1). Higher temperature seems to have similar effects on the peptides' secondary structure if SDS acts as a denaturant (i.e., below $\mathrm{cmc}$ ). The observed trends support the assumption that PPII conformation allows the polypeptide chain to switch easily to an $\alpha$-helical or $\beta$-sheet and $\beta$-turn conformation [31,39].

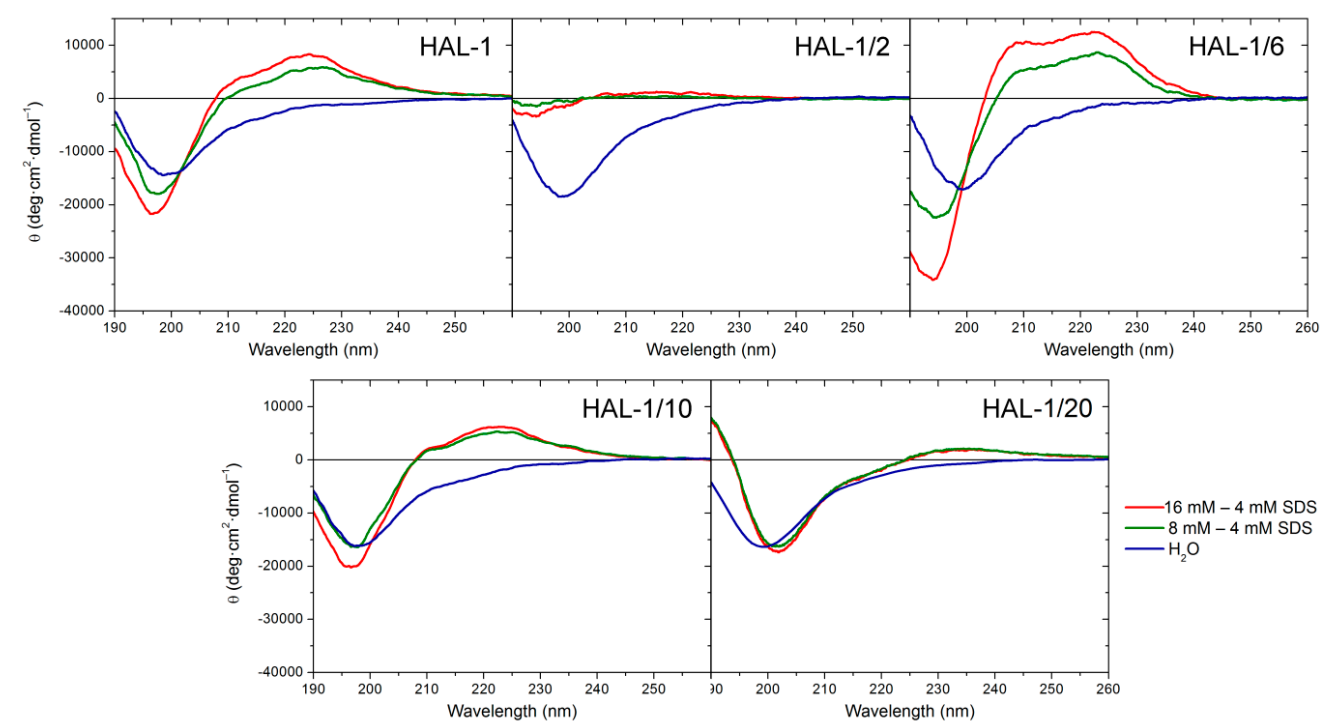

Figure 2. Difference of ECD spectra of HAL-1 and its analogs $(0.125 \mathrm{mg} / \mathrm{mL})$ in $8 \mathrm{mM}$ SDS and in $16 \mathrm{mM}$ SDS. ECD spectrum of the sample with the highest $\alpha$-helical content in SDS solution (4 mM SDS peptide solution for HAL-1/2, HAL-1/6, HAL-1/10, and 0.16 mM SDS peptide solution for HAL-1/20 is taken as a reference). ECD spectra of the peptides in aqueous solution are depicted for comparison. 


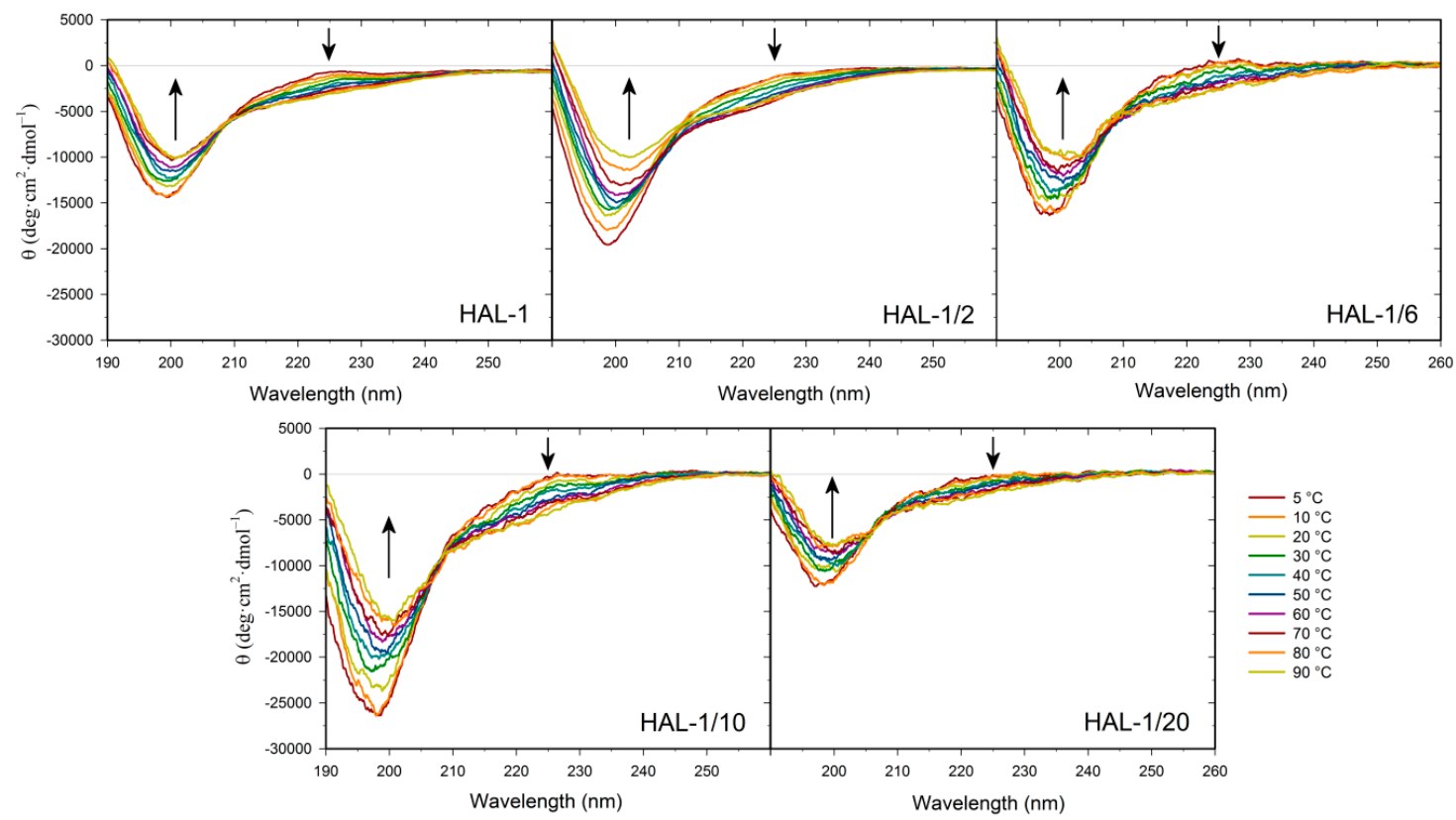

Figure 3. Thermal dependence of ECD spectra of HAL-1 and its analogs $(0.125 \mathrm{mg} / \mathrm{mL})$ in aqueous solution. The arrows show the direction of spectral changes with temperature increase from 5 to $90{ }^{\circ} \mathrm{C}$ (with a step of $10^{\circ} \mathrm{C}$ ).

\subsubsection{Structural Changes Due to the Presence of LUVs}

Neutral large unilamellar vesicles (LUVs) composed of PC were used as simple models of mammalian membranes. Similar to the natural HAL-1 [23], only subtle structural changes are observed in the ECD spectra of all the HAL-1 analogs upon addition of PC-based LUVs (Figure 4, Table A3). Slight conformational changes observed for HAL-1/2 and HAL-1/20 (Figure 4) likely correspond to an increase of $\beta$-sheet proportion. For HAL- 1 and in part also for HAL-1/6, an $\alpha$-helical structure can be induced when very high lipid/peptide $(\mathrm{L} / \mathrm{P})$ ratios $(\sim 600)$ are used (not shown). However, under such conditions, thorough analysis of ECD data is rather difficult due the limitations of ECD experiments (at high lipid concentrations, ECD spectra may be obscured due to light scattering on liposome molecules). The ability of all HAL-1 peptides to form the $\alpha$-helical structure is enhanced in the presence of negatively charged PG-containing LUVs, representing a simple bacterial membrane model. Similar to HAL-1, for the proline-containing analog HAL-1/2, this enhancement is maximized with liposomes containing the highest fraction of PG (PC/PG =1:4). For the other analogs, the maximal $\alpha$-helical content is observed for the liposomes having the same fraction of PC and PG (PC/PG = 1:1) while an additional formation of $\beta$-structure occurs in the presence of the liposomes with the highest fraction of PG (PC/PG = 1:4) (Table A3). In order to obtain additional information about the structural stability of the peptides in the presence of PC/PG liposomes (composed of PC/PG in the 1:4 ratio), a time dependence of ECD spectra in the 280-min time interval has been studied for HAL-1 and its analogs HAL-1/2, HAL-1/ 6 and HAL-1/20 (Figure 5). The most pronounced spectral changes with time have been observed for HAL-1/20. This peptide shows the highest tendency to form a $\beta$-structure immediately upon interaction with PC/PG liposomes. A portion of the $\alpha$-helical structure increases with time to a similar degree as for HAL-1/2. Following the PCA results (Figure A2), this structural change is compensated by a continuous $\beta$-structure content decrease. The structural behavior of HAL-1 seems to be comparable to HAL-1/6, with relatively small structural changes represented by a slight increase of the $\alpha$-helical content. As expected, only minor structural changes are observed for HAL-1/2 (Figure 5). 


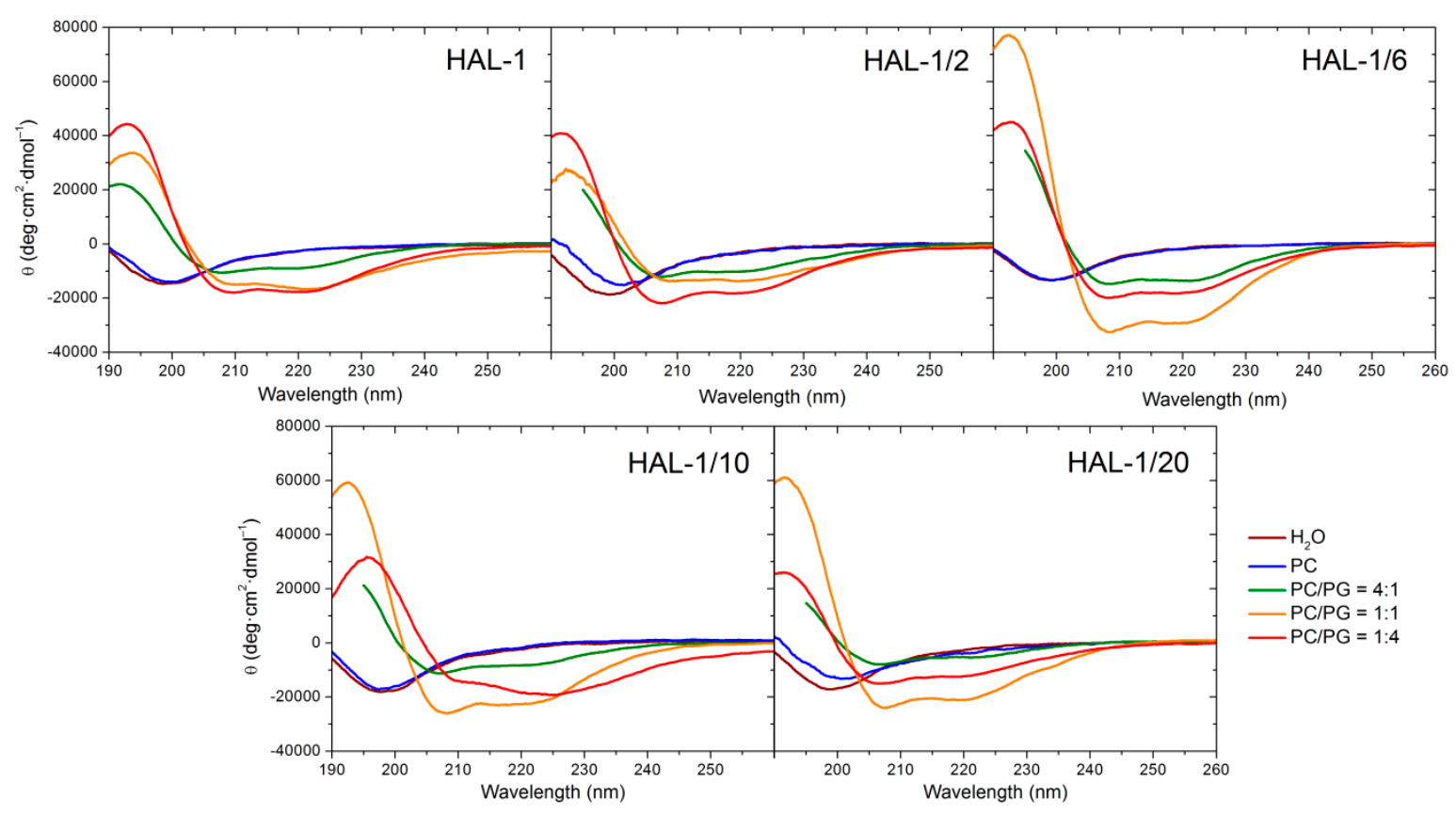

Figure 4. ECD spectra of HAL-1 and its analogs $(0.125 \mathrm{mg} / \mathrm{mL})$ in aqueous solution and in the presence of LUVs $(\mathrm{L} / \mathrm{P}=20)$ prepared from PC and PC/PG mixtures: 4:1, 1:1 and 1:4.

Since the liposomes composed of PC/PG in various ratios roughly simulate bacterial and mammalian membranes, an attempt can be made to correlate the secondary structure changes inferred from the experimental ECD spectra with the peptide biological properties. The observed very limited interactions of HAL-1 analogs with the mammalian membrane (PC-based) models seem to correlate with their low (or none) hemolytic activities. Rather hemolytic analogs HAL-1 and HAL-1/ 6 show some reduced tendency to form the $\alpha$-helical structure but such conformational change is induced only by a significant increase in lipid concentration. This is probably caused by the fact that the peptide activity against mammalian cells is much lower $(\sim 10-100 \times)$ than against bacterial cells, and the peptide propensity to interact with mammalian membrane model is therefore notably reduced. Behavior of the HAL-1 peptides towards PG-containing LUVs is very different. According to our data, all the HAL-1 analogs show a tendency to become $\alpha$-helical upon this interaction. As the highest $\alpha$-helical fraction is observed for HAL-1/6, which is less active than the native HAL-1, it seems that biological activities of the peptides are not solely determined by their propensity for forming an $\alpha$-helical structure. The spectral changes observed for the HAL-1 analogs in interaction with liposomes of various PC/PG compositions indicate that, similar to the peptide behavior in the presence of SDS micelles (see above), an additional formation of $\beta$-structure and/or PPII conformation cannot be excluded and could be also important for their biological activities. 


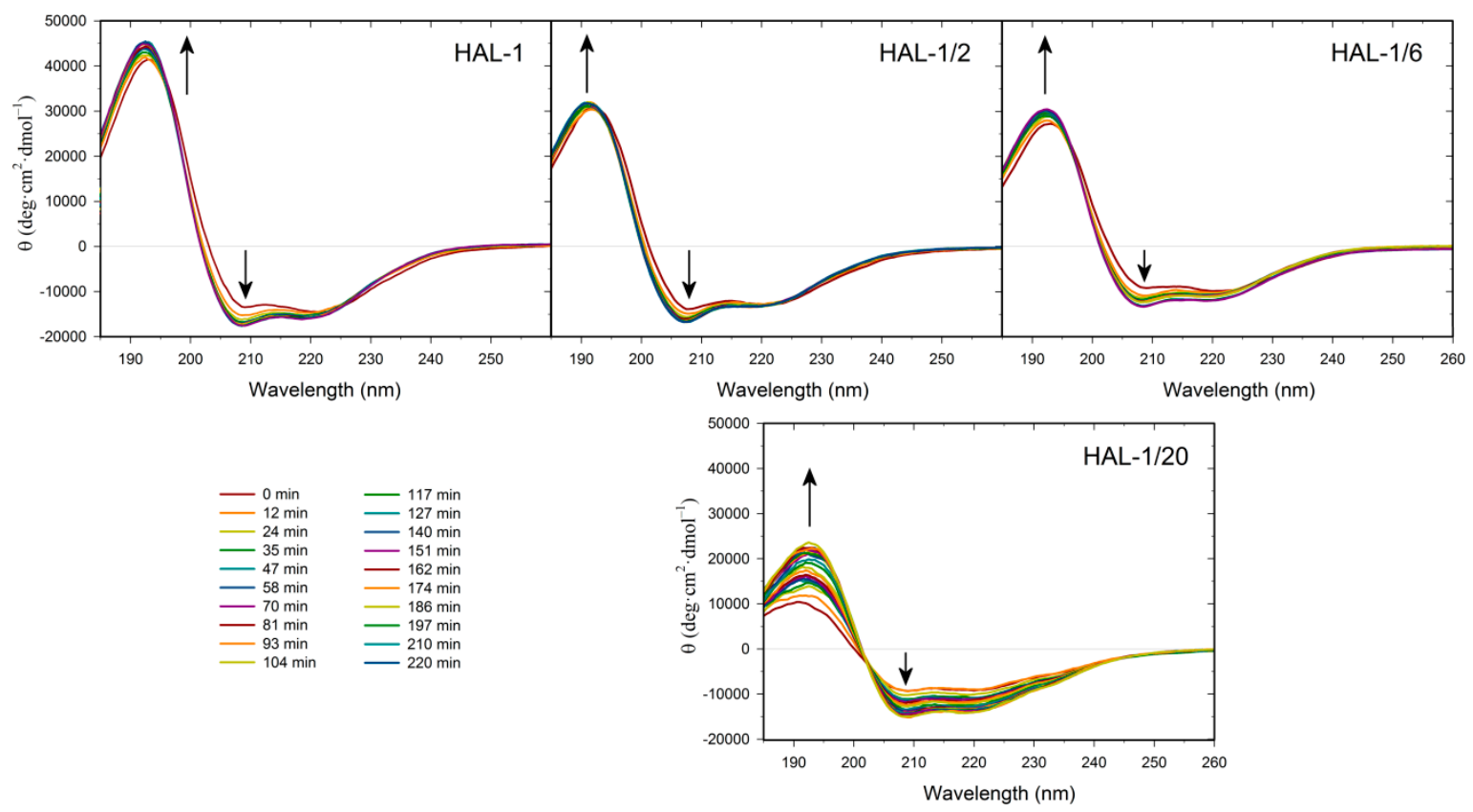

Figure 5. Time dependence of ECD spectra of HAL-1 and its analogs $(0.125 \mathrm{mg} / \mathrm{mL})$ in PC/PG $=1: 4$ mixtures $(\mathrm{L} / \mathrm{P}=20)$, measured within a 280 -min time interval after the sample preparation with a 12-min step. The arrows show the direction of spectral changes with time.

\subsection{Structural Changes Followed by Infrared Spectroscopy}

IR spectroscopy is sensitive to the $\beta$-sheet and $\beta$-turn structure and its combination with ECD may provide further conformational details. IR experiments can be carried out in aqueous solution $\left(\mathrm{H}_{2} \mathrm{O}\right.$ or $\left.\mathrm{D}_{2} \mathrm{O}\right)$, and the structure assignment is based on band positions within the amide I region $\left(1600-1700 \mathrm{~cm}^{-1}\right)$. For the peptides measured in $\mathrm{H}_{2} \mathrm{O}$, it is usually difficult to distinguish between the $\alpha$-helical and disordered structures because the corresponding amide I bands can occur in the same spectral range. This problem may be partially solved using hydrogen/deuterium exchange, which significantly reduces the $\alpha$-helix and disordered structure amide I band overlaps [41]. For the natural HAL-1 measured in $\mathrm{H}_{2} \mathrm{O}$, the amide I band positioned at $\sim 1646 \mathrm{~cm}^{-1}$ indicates that the peptide is mainly in a random coil conformation [42] with a minor contribution of $\beta$-turns (a shoulder at $\sim 1682 \mathrm{~cm}^{-1}$ ) [43]. Such assignment is confirmed by the IR measurements in $\mathrm{D}_{2} \mathrm{O}$, where a band at $\sim 1641 \mathrm{~cm}^{-1}$ (Figure 6, Table A4) can be again assigned to the random coil structure and bands at $\sim 1658$ and $1675 \mathrm{~cm}^{-1}$ to $\beta$-turns [41]. Upon addition of TFE (10-50\% v/v), IR spectra of HAL-1 exhibit a blue shift of the amide I band from $\sim 1646$ to $\sim 1656 \mathrm{~cm}^{-1}$ (Figure 6, Table A4), suggesting a secondary structure change from the random coil to the $\alpha$-helical structure [42,43]. An additional band at $\sim 1630 \mathrm{~cm}^{-1}$ suggests an occurrence of a $\beta$-sheet structure, and a band at $\sim 1621 \mathrm{~cm}^{-1}$ indicates formation of intermolecular hydrogen bonds, typical for peptide aggregation [42,44]. The band at $\sim 1683 \mathrm{~cm}^{-1}$, due to the $\beta$-turn structure, remains at the same position. A similar spectral shift of the band at $\sim 1645 \mathrm{~cm}^{-1}$ to $1657 \mathrm{~cm}^{-1}$ indicating a conformational change from the random coil to the $\alpha$-helical structure is observed in the IR spectra of HAL-1 interacting with SDS (2-8 mM). In $8 \mathrm{mM}$ SDS, the presence of a shoulder at $\sim 1686 \mathrm{~cm}^{-1}$ together with a spectral band at $\sim 1631 \mathrm{~cm}^{-1}$ suggests formation of the $\beta$-sheet structure [23,41]. Spectral shift of the band at $\sim 1646$ to $1657 \mathrm{~cm}^{-1}$ can be interpreted in terms of a formation of the $\alpha$-helical structure. This assumption is confirmed by an analogous measurement of the same concentration dependence in $\mathrm{D}_{2} \mathrm{O}$ (Figure 6, Table A4) where the main spectral component shifts from $1641 \mathrm{~cm}^{-1}$ (a disordered structure) in $\mathrm{D}_{2} \mathrm{O}$ to $\sim 1650 \mathrm{~cm}^{-1}$ (an $\alpha$-helical structure [42]) in SDS at a concentration above $\mathrm{cmc}(8 \mathrm{mM})$. The high-frequency component at $\sim 1682 \mathrm{~cm}^{-1}$ downshifts to $1676 \mathrm{~cm}^{-1}$, most probably due to a $\beta$-sheet structure formation [42]. 
These findings are in agreement with the results of ECD analysis, showing that, besides the $\alpha$-helical structure, the $\beta$-sheet structure is also present.

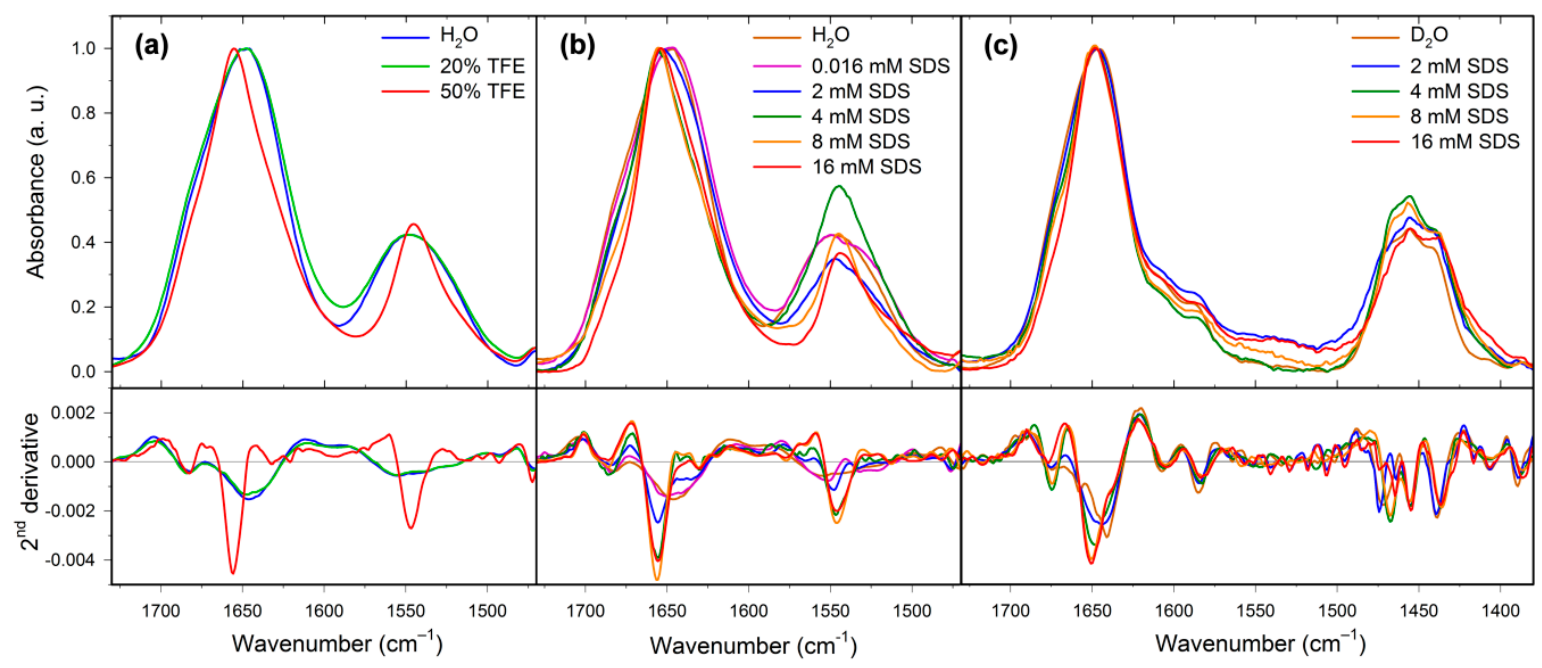

Figure 6. IR spectra (top) and their second derivatives (bottom) of HAL-1 (10 mg/mL) in (a) the presence of TFE $(0 \%, 20 \%$, and $50 \%)$; (b) of SDS $/ \mathrm{H}_{2} \mathrm{O}$ solution $(0.016,2,4,8$, and $16 \mathrm{mM} \mathrm{SDS})$. (c) of $\mathrm{SDS} / \mathrm{D}_{2} \mathrm{O}$ solution $(2,4,8$, and $16 \mathrm{mM}$ SDS).

IR spectrum of HAL-1/2 in $\mathrm{H}_{2} \mathrm{O}$ is dominated by a band at $\sim 1648 \mathrm{~cm}^{-1}$ due to the presence of a random coil structure. An additional band at $\sim 1684 \mathrm{~cm}^{-1}$ and a shoulder at $\sim 1636 \mathrm{~cm}^{-1}$ indicate a minor portion of $\beta$-turn and $\beta$-sheet conformation [42]. Upon addition of SDS, the band at $1648 \mathrm{~cm}^{-1}$ diminishes and a dominant component at $\sim 1655 \mathrm{~cm}^{-1}$ shows prevailing $\alpha$-helical structures. Addition of SDS again seems to cause a change in the $\beta$-structure arrangement, as in $8 \mathrm{mM}$ SDS, there are only two corresponding bands at $\sim 1686$ and $1639 \mathrm{~cm}^{-1}$. Formation of a low-frequency band at $\sim 1623 \mathrm{~cm}^{-1}$ indicates a partial peptide aggregation. Similar to HAL-1, IR spectrum of HAL-1/6 in water (Figure 7) is dominated by an amide I band at $\sim 1646 \mathrm{~cm}^{-1}$ indicating prevailing random coil structure, and a lower-intensity component at $\sim 1682 \mathrm{~cm}^{-1}$ assigned to $\beta$-turns [42]. Upon addition of SDS, the main amide I component shifts to $\sim 1655 \mathrm{~cm}^{-1}$ (in $8 \mathrm{mMSDS}$ ), again hinting at a transition from a random coil to an $\alpha$-helical structure. This process is accompanied by diminishing of the $\beta$-turn band at $\sim 1682 \mathrm{~cm}^{-1}$ and formation of a band at $\sim 1694 \mathrm{~cm}^{-1}$, implying a conformational change from the $\beta$-turn to $\beta$-sheet conformation [42]. IR spectrum of HAL-1/10 (Figure 7, Table A4) in $\mathrm{H}_{2} \mathrm{O}$ has the main feature at $\sim 1643 \mathrm{~cm}^{-1}$ which can be assigned either to the random coil, or the $\beta$-sheet structure [41,42]. As for HAL-1, a lower-intensity band at $\sim 1681 \mathrm{~cm}^{-1}$ suggests the presence of $\beta$-turns [42]. Conformational behavior of HAL-1/10 upon addition of SDS is practically the same as for HAL-1/ 6 (not shown). While the IR spectrum of HAL-1/20 (Figure 7, Table A4) in $\mathrm{H}_{2} \mathrm{O}$ is (similar to HAL-1/10) dominated by a band at $\sim 1642 \mathrm{~cm}^{-1}$ due to either random coil, or $\beta$-sheet structure [41,42], a shoulder at $\sim 1656 \mathrm{~cm}^{-1}$ indicates, in this case, a minor contribution of the $\alpha$-helical structure [42]. Upon addition of SDS, the band at $\sim 1642 \mathrm{~cm}^{-1}$ diminishes and a new band at $\sim 1651 \mathrm{~cm}^{-1}$ is formed, indicating a conformational change to $\alpha$-helical and/or random coil structure. The higher-frequency component, which shifts to $\sim 1659 \mathrm{~cm}^{-1}$, can be assigned to a $3_{10}$-helix [45]. In addition, we observe a new band at $\sim 1692 \mathrm{~cm}^{-1}$, reflecting the $\beta$-sheet structure formation [42]. 


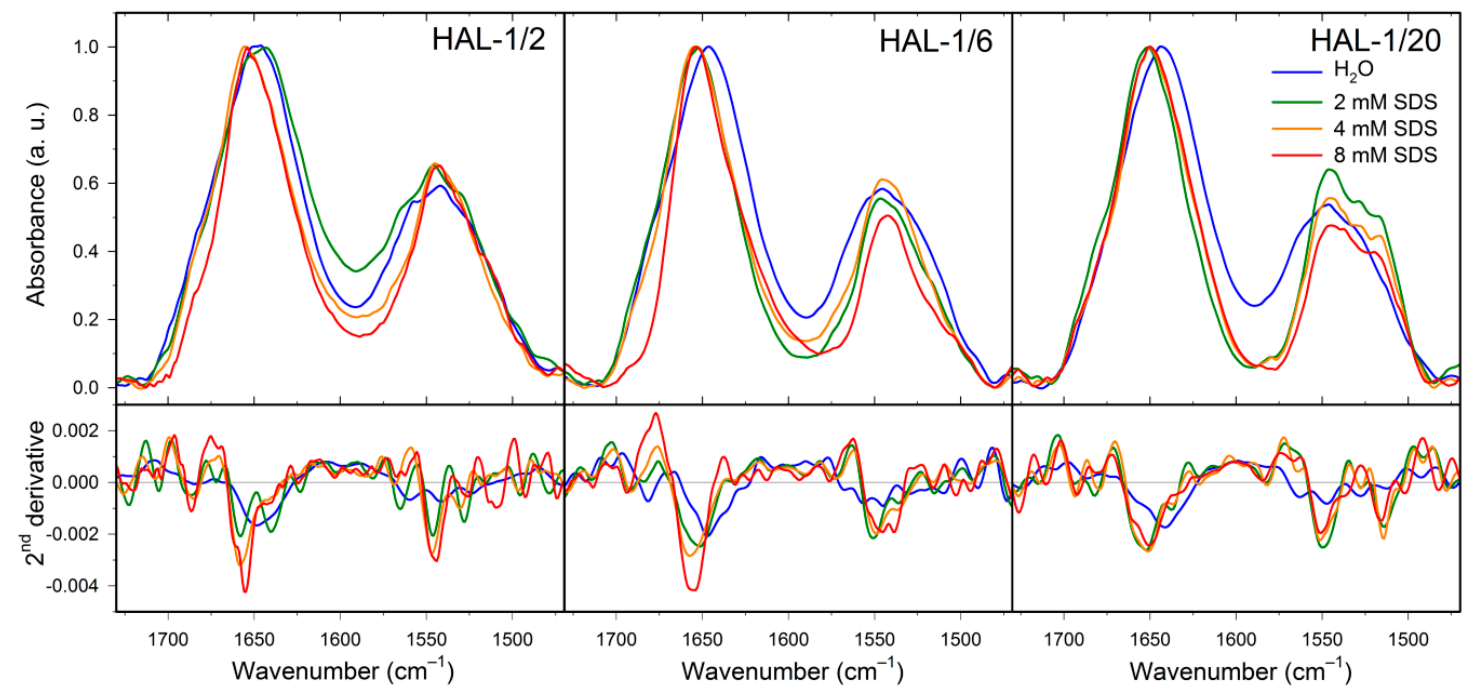

Figure 7. IR spectra (top) and their second derivatives (bottom) of HAL-1/2, HAL-1/6 and HAL-1/20 $(10 \mathrm{mg} / \mathrm{mL})$ in the presence of SDS $(0,2,4$, and $8 \mathrm{mM})$.

We have already shown that the secondary structure of HAL-1 in interaction with LUVs depends on LUV composition [23]. In the presence of neutral PC-based liposomes (a model of a mammalian membrane [1]), the dominant amide I band shifts to $\sim 1652 \mathrm{~cm}^{-1}$ probably due to the simultaneous presence of a random coil and an $\alpha$-helical structure. Bands at $\sim 1686$ and $1619 \mathrm{~cm}^{-1}$ relate to the formation of $\beta$-turns and $\beta$-sheet aggregates (Table A3). With an increasing fraction of negatively charged PG in the liposomes, the $\beta$-aggregates (the band at $\sim 1619 \mathrm{~cm}^{-1}$ ) almost disappear and the $\alpha$-helical structure content increases (formation of a band at $\sim 1655 \mathrm{~cm}^{-1}$ ) with a continuous diminishing of the $\beta$-turn content (the band at $\sim 1686 \mathrm{~cm}^{-1}$ ). IR spectra of HAL-1/2 (Figure 8, Table A4) display a notable spectral shift of the amide I band (from $\sim 1648$ to $1656 \mathrm{~cm}^{-1}$ ) already in the presence of neutral PC-based liposomes indicating a conformational change from an unordered to the $\alpha$-helical structure. The highest $\alpha$-helical fraction is observed for HAL-1/2 interacting with negatively charged liposomes composed of PC/PG in a 1:4 ratio. An increase in $\alpha$-helical structure content is accompanied by diminishing of the $\beta$-sheet bands (at $\sim 1640$ and $1690 \mathrm{~cm}^{-1}$ ) and also some minor changes in the $\beta$-turn arrangement (a slight shift of the band at $\sim 1685 \mathrm{~cm}^{-1}$ to $1681 \mathrm{~cm}^{-1}$ ). Similar to HAL-1/2, the formation of a band at $\sim 1657 \mathrm{~cm}^{-1}$, indicating an increase in the $\alpha$-helical structure content, is observed also for HAL-1/ 6 upon addition of neutral PC-based liposomes (Figure 8). An additional band at $\sim 1639 \mathrm{~cm}^{-1}$ is probably due to the $\beta$-sheet structure formation. 

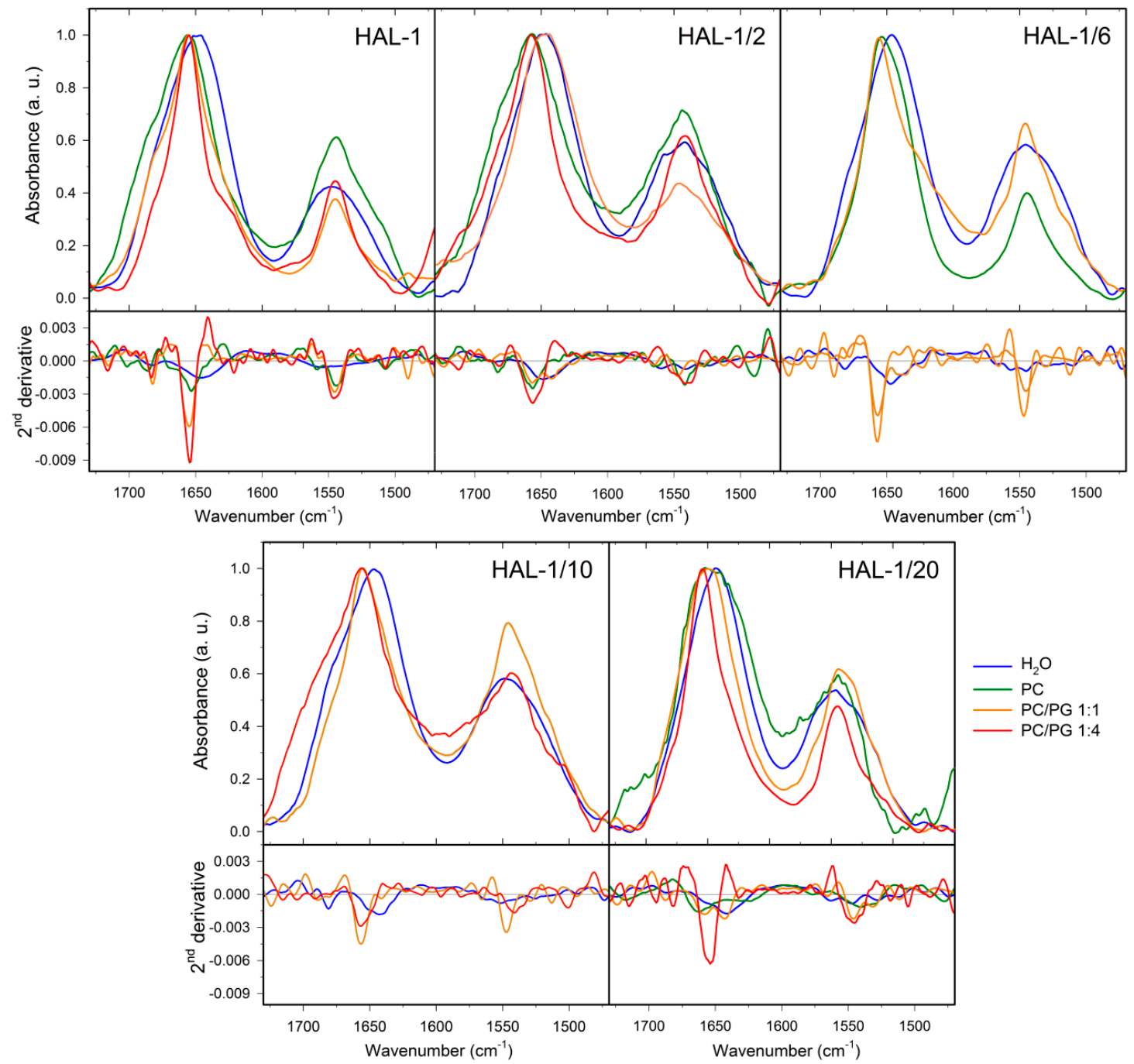

Figure 8. IR spectra (top) and their second derivatives (bottom) of HAL-1 and its analogs (10 mg/mL) in the presence of LUVs having different composition: in aqueous solution and in the presence of LUVs prepared from PC and PC/PG mixtures: 1:1 and 1:4.

For HAL-1/10 in the presence of LUVs, with an increasing fraction of PG in the liposomes, we observe diminishing of the band at $\sim 1643 \mathrm{~cm}^{-1}$ and formation of a band at $\sim 1656 \mathrm{~cm}^{-1}$, indicating again a transition from $\beta$-sheet and/or random coil structure to $\alpha$-helical structure. This process is accompanied by diminishing of the band at $\sim 1681 \mathrm{~cm}^{-1}$ assigned to $\beta$-turns and formation of a band at $\sim 1690 \mathrm{~cm}^{-1}$ probably due to $\beta$-sheet structure occurrence [41,42] (Figure 8, Table A4). FTIR spectra of HAL-1/20 in the presence of neutral PC-based liposomes indicate the formation of $\beta$-sheet aggregates (band at $\sim 1626 \mathrm{~cm}^{-1}$ ). A dominant spectral component at $\sim 1663 \mathrm{~cm}^{-1}$ can be probably assigned to the $3_{10}$-helical structure. These two spectral features disappear with an increasing fraction of PG in the liposomes and we observe formation of a band due to the $\alpha$-helical structure (positioned at $\sim 1658$ and $1654 \mathrm{~cm}^{-1}$ in the presence of liposomes composed of PC/PG in the 1:1 and 1:4 ratio, respectively). For this analog, bands assigned to the $\beta$-sheet (at $\sim 1634$ and $1694 \mathrm{~cm}^{-1}$ ) and $\beta$-turn structures (at $\sim 1681 \mathrm{~cm}^{-1}$ ) can be observed even in the presence of liposomes with the highest PG fraction (PC/PG in the 1:4 ratio).

IR spectroscopy confirms induced conformational change from the random coil to the $\alpha$-helical structure in the biologically active HAL-1 analogs upon interaction with the bacterial membrane models and complements ECD results by providing information about the $\beta$-structure formation. Based on the results of IR analysis, spectral changes in ECD curves observed for the peptides interacting 
with SDS in concentration far above cmc and for PG-containing LUVs are probably due to changes in the $\beta$-sheet content. Behavior of HAL-1 peptides towards LUVs reveals (a) in accordance with biological data, the most active natural HAL-1 shows the lowest tendency to form $\beta$-aggregates and the $\beta$-sheet structure upon interaction with PG-containing LUVs; (b) contrary to the ECD results, all HAL-1 analogs adopt some portion of the $\alpha$-helical structure already in the presence of neutral liposomes (representing a crude model of mammalian cells, against which the peptides have no or very low activity). This rather surprising conformational behavior could be caused by different experimental conditions used for the measurements of IR and ECD spectra (IR experiments require $\sim 100 \times$ higher peptide concentration than ECD measurements, see experimental conditions for ECD and IR measurements in the Materials and Methods section). It seems that under such conditions, the peptides tend to form specific assemblies, adopting a conformation with a high $\alpha$-helical content.

\subsection{Concentration Dependence Measurements}

In order to clarify the discrepancy between the results of the peptide conformational analyses obtained by ECD and IR, we have complemented our study by a measurement of concentration dependencies of ECD spectra of the HAL-1 peptides (Figure 9). Our ECD data indicate that with increasing peptide concentration, the unordered/PPII conformation changes to a partially $\alpha$-helical conformation for all the studied analogs except for HAL-1/2, which seems to form $\beta$-aggregates when its concentration reaches $100 \mathrm{mg} / \mathrm{mL}$. In order to determine the peptide conformational change induced by its high concentration more specifically, we have performed measurements of VCD spectra of the peptides (Figure 10) using the highest peptide concentration studied by ECD (i.e., $100 \mathrm{mg} / \mathrm{mL}$ ). VCD measurements supported the results of ECD analysis, confirming that at high peptide concentration, HAL-1 and its analogs HAL-1/6, HAL-1/10, and HAL-1/20 spontaneously form the $\alpha$-helical structure, indicated by a negative/positive VCD couplet in the amide I region [46-48]. On the contrary, the HAL-1/2 analog (Figure 10b) seems to undergo a distinct conformational change, forming highly organized $\beta$-sheet aggregates ( $\beta$-sheet fibrils) characterized by an intense five-peak VCD signal with the $(-/-/+/-/-)$ sign pattern in the amide I and II region [49-51]. Interestingly, a tendency to form the $\alpha$-helical structure at high peptide concentration is common for all the HAL- 1 analogs except for HAL-1/2, which exhibits the most reduced biological activity. It is therefore possible that for the peptide biological action, formation of specific assemblies with a high $\alpha$-helical content might be also important.

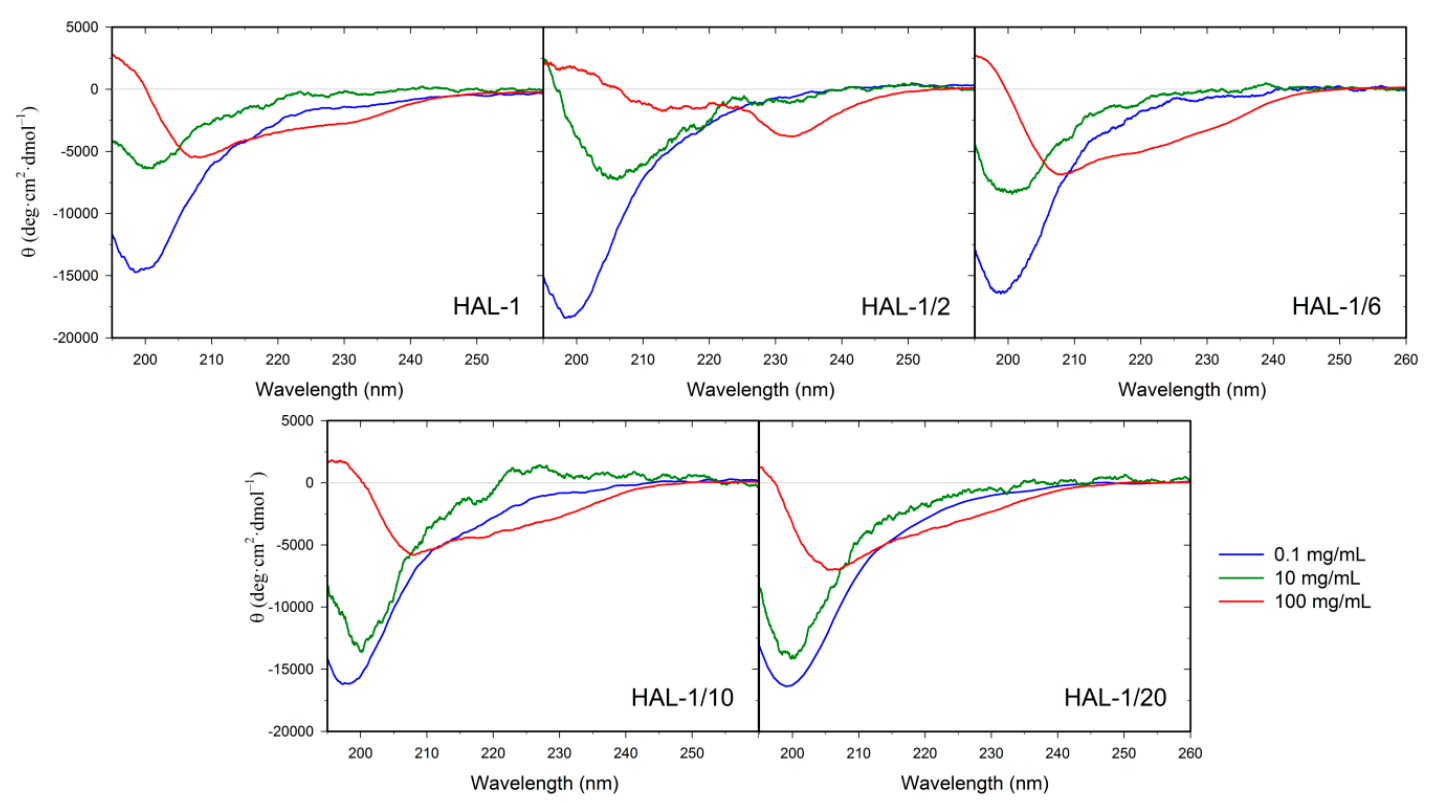

Figure 9. Concentration dependence of ECD spectra of HAL-1 and its analogs: $0.1,10,100 \mathrm{mg} / \mathrm{mL}$. 


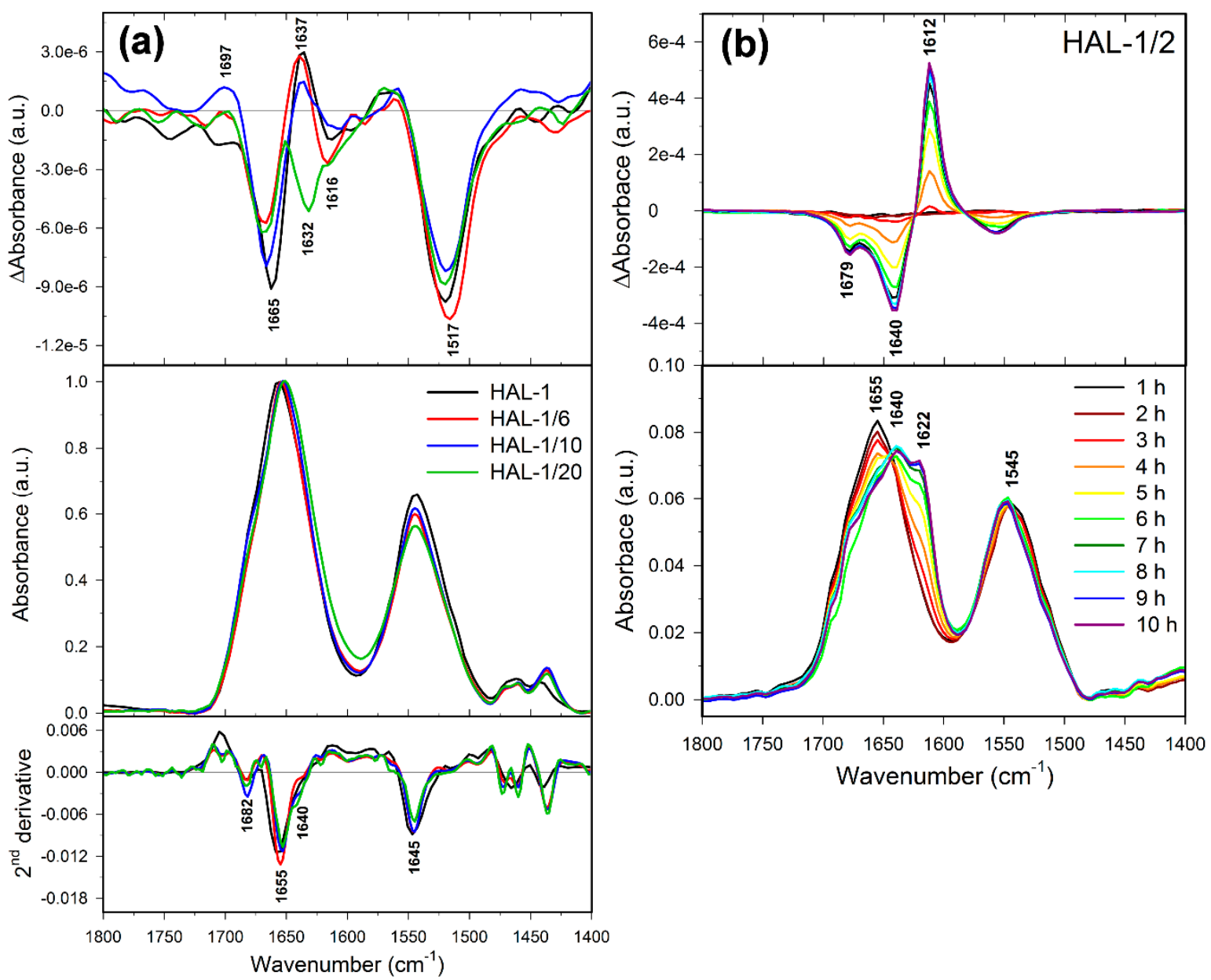

Figure 10. (a) VCD (top)/IR (middle)/second derivatives of IR spectra (bottom) of HAL-1, HAL-1/6, HAL-1/10, and HAL-1/20 in aqueous solution for samples in the $100 \mathrm{mg} / \mathrm{mL}$ concentration; (b) time dependence (1-10 h after preparation) of VCD (top) and IR spectra (bottom) of HAL-1/2 in aqueous solution for the sample in the $100 \mathrm{mg} / \mathrm{mL}$ concentration.

\subsection{Structural Changes Followed by Fluorescence Spectroscopy}

Participation of the tryptophan residue in the interaction of HAL-1 peptides with SDS and LUVs can be monitored selectively on the basis of fluorescence spectra. The observed fluorescence signals are assigned to the Trp3 residue. In aqueous solutions, the peptides exhibit fluorescence maxima at $360 \mathrm{~nm}$ (HAL-1), $356 \mathrm{~nm}$ (HAL-1/2), $361 \mathrm{~nm}$ (HAL-1/6) and $359 \mathrm{~nm}$ (HAL-1/20) (Table 2), i.e., the typical values for Trp residue in a hydrophilic environment. Upon interaction with LUVs, these maxima shift to about $330 \mathrm{~nm}$ (Table 2) indicating that tryptophan is not fully immersed in the lipophilic part of the liposome, but it is still in a close proximity of liposome phosphate heads [52]. In the case of HAL-1/2, the fluorescence maximum shifts only to $350 \mathrm{~nm}$. Hence, it is probable that HAL-1/2 while interacting with LUVs, does not incorporate itself into the liposome despite the fact that parallel ECD experiments indicate a formation of some $\alpha$-helical secondary structure. This result confirms our assumption that the $\alpha$-helix formation is an important but not a sufficient condition for the efficient functioning of our AMPs. This conclusion is further supported by the results shown by HAL-1/6. Although HAL-1/ 6 readily interacts with LUVs by forming the $\alpha$-helical structure, its biological activity is smaller than the activity of the natural HAL-1. Fluorescence spectroscopy shows that HAL-1 peptides are attached to the membrane surface with little penetration, indicating that the HAL-1 peptide mode of action probably involves either (a) dissolving the membrane in a detergent-like manner (the carpet model) or (b) formation of toroidal-type trans-membrane pores (lined both by peptide molecules and phospholipid headgroups) [53]. 
Table 2. Tryptophan fluorescence maxima of HAL- 1 and its analogs $(0.125 \mathrm{mg} / \mathrm{mL}$-identical as for the ECD experiments) in aqueous solution and in the presence of LUVs $(\mathrm{L} / \mathrm{P}=20)$.

\begin{tabular}{ccccc}
\hline Solution & HAL-1 & HAL-1/2 & HAL-1/6 & HAL-1/20 \\
\hline Water & $360 \mathrm{~nm}$ & $356 \mathrm{~nm}$ & $361 \mathrm{~nm}$ & $359 \mathrm{~nm}$ \\
PC & $356 \mathrm{~nm}$ & $362 \mathrm{~nm}$ & $356 \mathrm{~nm}$ & $359 \mathrm{~nm}$ \\
PC/PG $(1: 1)$ & $331 \mathrm{~nm}$ & $350 \mathrm{~nm}$ & $336 \mathrm{~nm}$ & $333 \mathrm{~nm}$ \\
\hline
\end{tabular}

\subsection{Molecular Dynamics}

As follows from the fluorescence spectroscopy measurements, HAL-1 peptides seem to bind to the outer leaflet of our model membranes. In order to better understand the mechanism of peptide-membrane interaction, we performed MD simulations of HAL-1 in water and in the presence of PC and PG-based model membranes. According to our results, HAL-1 in water is in a random coil conformation (Figure 11). When in the vicinity of a PC containing membrane, HAL-1 does not immerse into the membrane and it seems to have no defined orientation with regards to the membrane. HAL-1 does not change its structure and it still adopts a random coil conformation. The result of this simulation might seem rather surprising: Although the peptide exhibits hemolytic activity, we do not observe any peptide-membrane interaction. However, as follows from our spectroscopic results (see Section 2.3), HAL-1 structural behavior is concentration dependent and it is therefore probable that for its full activity, it is necessary to exceed a certain peptide threshold concentration. Under such conditions, the peptide might form specific assemblies (e.g., pores) that would allow for the peptide-membrane interaction [54].
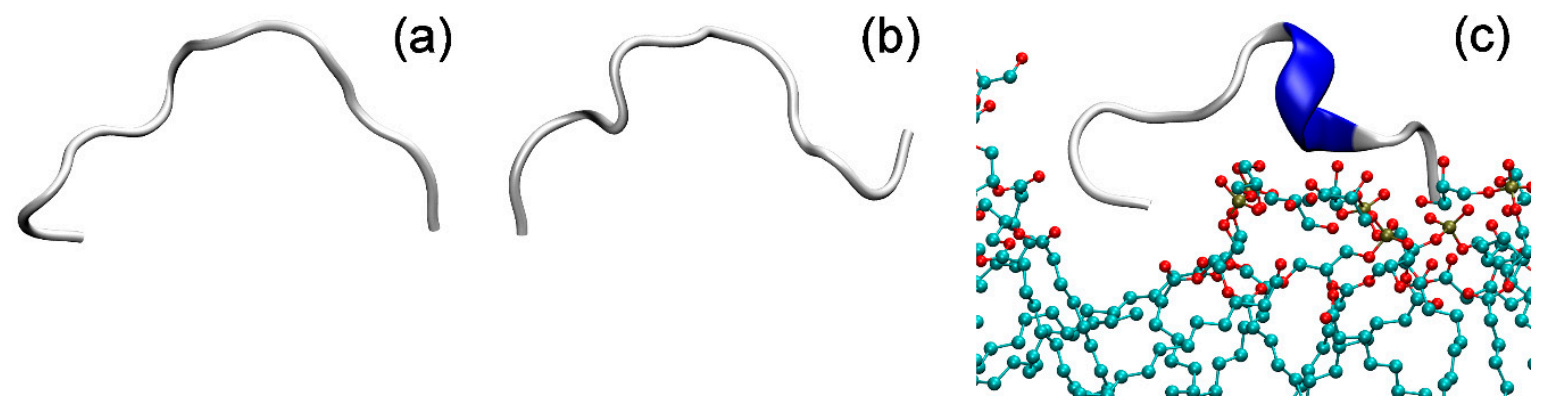

Figure 11. Molecular mechanic simulation of HAL-1 peptide (a) in water, (b) in the presence of PC and (c) PG model membrane.

When put into interaction with the PG based membrane, HAL-1 is anchored to the membrane by the terminal amino acid Arg. The peptide does not penetrate into the membrane and for the simulation time (110 ns) it stays in the vicinity of the membrane (Figure 11), which is in agreement with the fluorescence spectroscopy results, showing that tryptophan is in close proximity to the liposome phosphate heads (see Section 2.4). Based on the MD simulations, HAL-1 in a bacterial membrane-mimicking environment adopts mostly a $3_{10}$-helical structure with a minor portion of the $\beta$-turn structure (Figure 11). Such a result does not contradict the ECD and IR data (suggesting under such conditions, formation of the $\alpha$-helical conformation), as it was shown that the $3_{10}$-helix is an important intermediate along the $\alpha$-helix folding/unfolding pathway [55].

Based on the results of our spectroscopic investigation and MD simulations, we suggest a mechanism of HAL-1 interaction with model membranes: HAL-1 as a cationic peptide is mostly attracted to the negatively charged leaflets of the PG based model membranes, adopting predominantly a 310 -helical conformation - an intermediate conformation and/or a precursor of the $\alpha$-helical structure [55]. Since the peptide in such conformation already adopts an amphipathic structure, formation of peptide assemblies (most probably membrane pores), where the peptides are predominantly in the $\alpha$-helical conformation, seems favorable. However, for the formation of 
such assemblies, it is necessary to exceed a specific threshold concentration of the peptide in a close proximity or in an immediate contact with the membrane. The proposed mechanisms of action are inspired by the molecular mechanisms of cooperativity of antibacterial peptides proposed by Huang et al. [54,56], and correspond to the mechanism and dynamics of AMP channel formation monitored in situ, where at least a three-step procedure of AMP insertion was suggested and the importance of the peptide-peptide interaction was demonstrated [57]. Several steps need to be taken to confirm this hypothesis: (1) It would be beneficial to perform more profound MD simulations of all HAL-1 analogs interacting with membranes of different composition. A peptide concentration dependency should be studied, investigating two or more peptides that interact on a membrane surface; (2) this computational study should be complemented by experiments allowing detailed study of peptide orientation with respect to the membrane such as oriented ECD [54], surface-enhanced infrared absorption spectroscopy [57], or oriented solid-state NMR measurements [58]. This will be a matter of further investigation.

\section{Materials and Methods}

\subsection{Materials}

The phospholipids, PC, and PG (sodium salt), were purchased from Avanti Polar Lipids (Alabaster, AL, USA). TFE was purchased from Merck (Darmstadt, Germany) and SDS from Sigma (Darmstadt, Germany). The peptides (see Table 1) were prepared by the standard procedures of solid phase peptide synthesis [19]. All the peptides were delivered as TFA salts (with TFA counterions bonded to the free amino termini and side chains of positively charged amino acids). For the natural HAL-1, it was possible to remove TFA counterions using a standard procedure [59] as there was a sufficient amount of the sample available.

\subsection{Preparation of Vesicles}

The phospholipids PC, PG or their mixtures (at 1:4, 1:1 or 4:1 molar ratios) were dissolved in chloroform/methanol (3:1) mixture and dried under vacuum. The dry lipid layer was hydrated with distilled water and gently stirred. LUVs with an approximate diameter of $0.1 \mu \mathrm{m}$ were formed by extrusion through polycarbonate membranes (pore size $0.1 \mu \mathrm{m}$, a total of 30 passages through the membrane) using Mini-Extruder (Avanti Polar Lipids, Alabaster, AL, USA). The temperature of the lipid suspension was kept above the phase transition temperature $T_{\mathrm{m}}$ of the lipid with the highest $T_{\mathrm{m}}$ within the whole hydration and extrusion process. A liposome size of $0.1 \mu \mathrm{m}$ was selected in order to avoid artifacts due to light scattering (especially in ECD experiments). The shapes and sizes of liposomes were checked by cryo-electron microscopy. Liposome stabilities and size distributions were verified by light scattering using Zetasizer Nano (Malvern Panalytical, Malvern, UK).

\subsection{Electronic Circular Dichroism}

ECD experiments were carried out on J-815 spectropolarimeter (Jasco, Tsukuba, Japan) equipped with the Peltier type temperature control system PTC-423S/L. The spectra were collected from 180 to $300 \mathrm{~nm}$ at room temperature in $0.1 \mathrm{~cm}$ quartz cells $(0.125 \mathrm{mg} / \mathrm{mL}$ peptide concentration, 2 scans, $0.5 \mathrm{~nm}$ steps, $20 \mathrm{~nm} / \mathrm{min}$ speed, $8 \mathrm{~s}$ time constant, $1 \mathrm{~nm}$ spectral bandwidth). For the measurements in high liposome concentration (L/P concentration ratio higher than 100), the cell with $0.02 \mathrm{~cm}$ path length and appropriate experimental conditions ( $5 \mathrm{~nm} / \mathrm{min}$ speed, $32 \mathrm{~s}$ response time and $1 \mathrm{~nm}$ bandwidth) were used. After baseline subtraction, the final data were expressed as molar ellipticities $\theta\left(\mathrm{deg} \cdot \mathrm{cm}^{2} \cdot \mathrm{dmol}^{-1}\right)$ per residue. All samples were prepared by dilutions of a stock peptide solution $(1 \mathrm{mg} / \mathrm{mL})$ to a final peptide concentration $0.125 \mathrm{mg} / \mathrm{mL}$, followed by adding an appropriate aliquot of TFE (final TFE concentration 10-50\% v/v), SDS (stock solution $32 \mathrm{mM}$, final SDS concentration 0.016-16 mM, i.e., below and above $\mathrm{cmc} ; \mathrm{cmc} \approx 4 \mathrm{mM}$ for the SDS-peptides solution [60]), or LUVs (stock solution 
$200 \mathrm{mg} / \mathrm{mL}$ ). SDS measurements below and above $\mathrm{cmc}$ enable investigating the effects of SDS acting both as (a) a denaturation agent (below $\mathrm{cmc}$ ) and (b) a simple membrane model (above $\mathrm{cmc}$ ).

Concentration dependence was measured for all the peptides at the given concentrations: $0.1,10$, and $100 \mathrm{mg} / \mathrm{mL}$. The spectra were collected from 180 to $300 \mathrm{~nm}$ at room temperature in $0.1 \mathrm{~cm}$ quartz cells for the $0.1 \mathrm{mg} / \mathrm{mL}$ peptide concentration, and in $6 \mu \mathrm{m}$ homemade $\mathrm{CaF}_{2}$ cells for $10 \mathrm{mg} / \mathrm{mL}$ and $100 \mathrm{mg} / \mathrm{mL}$ peptide concentration with the following setup: 2 scans, $0.5 \mathrm{~nm}$ steps, $20 \mathrm{~nm} / \mathrm{min}$ speed, $8 \mathrm{~s}$ time constant, $1 \mathrm{~nm}$ spectral bandwidth. The $\alpha$-helical fraction was calculated using a two-state model $[30,61]$. For the more detailed analysis of secondary structure, we used the CDPro software package [36,62].

\subsection{Principle Component Analysis}

Analysis of temperature- and time-dependent ECD spectra was performed using principal component analysis (PCA) based on a singular value decomposition algorithm applied to reduce spectral series $\left\{Y_{\mathrm{i}}(v), i=1, \ldots, n\right\}$ to their lowest dimension without the loss of spectroscopic information. Each spectrum of the matrix $Y_{\mathrm{i}}(v)$ can be unambiguously expressed as:

$$
Y_{i}(v)=\sum_{j=1}^{M} V_{i j} W_{j} S_{j}(v)
$$

where $W_{j}$ is the diagonal matrix of singular values, $S(v)$ corresponds to the matrix of the orthonormal subspectra (eigenvectors) and $V_{i j}$ is the unitary square matrix of coefficients (representing the influence strength of the subspectrum $S_{j}$ ). $M$ represents a number of independent "spectral species", distinct from the spectral noise, found in the analyzed data set. The number of independent subspectra can be estimated from residual errors or from singular values. A detailed explanation of PCA can be found in [63]. The calculation of PCA was done using our own software programmed in Matlab ${ }^{\mathrm{TM}}$ (MathWorks ${ }^{\circledR}$, Natick, MA, USA).

\subsection{Infrared Spectroscopy}

IR spectra in the transmission mode were recorded on Nicolet 6700 spectrometer (Thermo Fisher Scientific, Waltham, MA, USA) using standard mid-IR source, KBr beamsplitter and DTGS detector ( $2 \mathrm{~cm}^{-1}$ spectral resolution, Happ-Genzel apodization function, $2000 \mathrm{scans}$ ) in the $4000-1000 \mathrm{~cm}^{-1}$ spectral range. The cell compartment was purged by dry nitrogen during all the measurements. Aqueous solutions $(10 \mathrm{mg} / \mathrm{mL}$ peptide concentration) were measured at room temperature in homemade $\mathrm{CaF}_{2}$ cells with $6 \mu \mathrm{m}$ path length (cell volume $1 \mu \mathrm{L}$ ). In our experiments involving peptide-membrane interaction, the L/P was always equal to 8 (LUVs stock solution $200 \mathrm{mg} / \mathrm{mL}$ ). Numerical data treatment was carried out using Grams/AI software (Thermo Electron, Waltham, MA, USA). The spectral contribution of water was eliminated using a standard algorithm [64]. The IR signal of phospholipids was subtracted from spectra of peptide/phospholipid mixtures. Subsequently, the spectrum of water vapors was subtracted and the baseline was linearly corrected. Final IR spectra were normalized to amide I intensity maxima. The IR spectra of HAL-1 analogs were obtained by additional subtraction of trifluoroacetate signals, which were present due to a standard cleavage from the resin by TFA [65]. Such subtraction was not needed for the natural HAL-1 as for this peptide, the TFA counterions were successfully removed (see Section 3.1). The secondary structure analysis [41] was aided using second derivatives Savitzky-Golay algorithm (Grams/AI software, Thermo Electron, Waltham, MA, USA) and a band fitting procedure (Gaussian-Lorentzian band shape-OMNIC Thermo Fisher Scientific, Waltham, MA, USA).

\subsection{Vibrational Circular Dichroism}

VCD spectra were measured on a dual source [66] and dual photo-elastic modulator [67] VCD spectrometer ChiralIR-2X ${ }^{\mathrm{TM}}$ (BioTools, Jupiter, FL, USA) at room temperature in $\mathrm{CaF}_{2}-\mathrm{BioCell}^{\mathrm{TM}}$ with 
$6 \mu \mathrm{m}$ path length (BioTools, Jupiter, FL, USA). The data were collected for $\sim 12 \mathrm{~h}$ (12 blocks of 6000 scans each at $8 \mathrm{~cm}^{-1}$ resolution). The spectra were processed in Grams/AI software (Thermo Electron, Waltham, MA, USA). Solvent scans were subtracted as background. Baseline was corrected using a linear function. The spectra were smoothed with a second-order Savitzky-Golay filter using a 9 point window and normalized to amide I maxima in the corresponding IR spectra.

\subsection{Fluorescence Spectroscopy}

Steady-state fluorescence spectra were measured on Fluoromax Z (Jobin-Yvon, Chilly-Mazarin, France) fluorimeter in a $10 \mathrm{~mm}$ quartz cell. Excitation at $280 \mathrm{~nm}$ was used to induce fluorescence of the tryptophan residue. The emission was collected from 300 to $450 \mathrm{~nm}$ with the $1.5 \mathrm{~s}$ integration time. The emission and excitation slits were chosen as $2 \mathrm{~nm}$. The peptide concentration of $0.125 \mathrm{mg} / \mathrm{mL}$ was chosen identical as for the ECD experiments in order to maintain mutual compatibility. At this low concentration, there is no danger of Trp residues self-quenching. $\mathrm{L} / \mathrm{P}=20$ was used for all the fluorescence measurements ( $2 \mathrm{mg} / \mathrm{mL}$ lipid concentration).

\subsection{Molecular Dynamics}

An all-atom structure model of the peptides was created using the tLEaP program from the AmberTools (San Francisco, CA, USA) [68] suite and the force field Amber FF99SB [69] PC and PG membrane models were created using program VMD [70] and its membrane plugin. PC and PG parameters were generated using programs Antechamber and Parmchk from the AmberTools suite. In total, three systems were created, a peptide in water and the peptide with PC and PG membranes. Each system was solvated in TIP3P water and neutralized using $\mathrm{K}^{+}$and $\mathrm{Cl}^{-}$ions. The initial equilibration of systems was performed using NAMD 2.9 [71] with a time step of 1 fs and rigid bonds in water molecules using Settle algorithm [72]. Systems were minimized for 1000 steps, warmed to $310 \mathrm{~K}$ and equilibrated for $1 \mathrm{ps}$. The system without a membrane was simulated for $10 \mathrm{ps}$, and the systems with membranes were simulated for $110 \mathrm{ps}$.

\section{Conclusions}

The combined use of the methods of molecular spectroscopy (ECD, IR absorption, VCD and fluorescence spectroscopy) together with MD simulations allowed us to follow secondary structure changes of HAL- 1 and its analogs induced by an interaction with artificial membrane models. On the basis of the obtained results, formation of the $\alpha$-helical structure appears important for the activity of the HAL-1 peptides. However, peptide biological activities seem to be determined not only by their propensity to form the $\alpha$-helical structure. Additional factors like the ability of the peptides to adopt alternative conformations (such as $\beta$-sheet, PPII conformation or $3_{10}$-helix) cannot be excluded and have to be considered for their biological activity as well. For biologically active analogs, the concentration-dependence ECD measurements together with VCD data suggest a possible formation of peptide assemblies high in $\alpha$-helical content (most probably membrane pores), which might enable membrane penetration. Following our spectroscopic results, we can propose that HAL-1 structural behavior is concentration dependent and for its full activity, certain peptide threshold concentration should be exceeded. Under such conditions, the peptides might form specific assemblies (e.g., pores) that would allow for the peptide-membrane interaction and complete their task as antimicrobial agents.

Author Contributions: Conceptualization, M.P. and L.B.; methodology, M.P., V.Z., L.B.; software, V.Z. and V.K.J.; formal analysis, M.P., K.H., V.K.J. and L.B.; investigation, M.P., V.Z., K.H., V.K.J., E.K., T.P. and L.B.; resources, E.K. and V.Č.; writing—original draft preparation, M.P., P.M. and L.B.; writing—review and editing, M.P., K.H., V.K.J., E.K., T.P. and L.B.; visualization, M.P., V.Z., K.H., V.K.J. and L.B.; supervision, L.B.; project administration, V.K.J. and L.B.; funding acquisition, V.K.J. and L.B.

Funding: This research was funded by the Czech Science Foundation, grant number 208/10/0376 and by Research Projects RVO, grant number 61388963. 
Acknowledgments: We would like to thank Rina K. Dukor (BioTools, USA) for allowing us to measure VCD spectra in their facility and to Jan Bednár (Institute de Biologie Structurale, France) for performing cryo-electron microscopy measurements of liposomes.

Conflicts of Interest: The authors declare no conflict of interest. The funders had no role in the design of the study; in the collection, analyses, or interpretation of data; in the writing of the manuscript, or in the decision to publish the results.

\section{Abbreviations}

$\begin{array}{ll}\text { AMPs } & \text { Antimicrobial peptides } \\ \text { cmc } & \text { Critical micelle concentration } \\ \text { ECD } & \text { Electronic circular dichroism } \\ \text { HAL } & \text { Halictine } \\ \text { IR } & \text { Infrared } \\ \text { L/P } & \text { Lipid/peptide ratio } \\ \text { LUV } & \text { Large unilamellar vesicle } \\ \text { MD } & \text { Molecular dynamics } \\ \text { PC } & \text { 1,2-Dimyristoyl-sn-glycerol-3-phosphatidylcholine } \\ \text { PCA } & \text { Principal component analysis } \\ \text { PG } & \text { 1,2-Dimyristoyl-sn-glycero-3-phospho-(1'-rac-glycerol) } \\ \text { PPII } & \text { Polyproline II } \\ \text { SDS } & \text { Sodium dodecyl sulfate } \\ \text { TFE } & \text { 2,2,2-Trifluoroethanol } \\ \text { VCD } & \text { Vibrational circular dichroism }\end{array}$

\section{Appendix A}

Table A1. Helical fraction for HAL-1 and its analogs in aqueous solution and in the presence of TFE (concentration expressed in volume percent $(v / v)$ ) and SDS (in $\mathrm{mM}$ ) calculated using a two-state model from ECD spectra $[30,61]$.

\begin{tabular}{cccccc}
\hline Solution & Hal-1 & Hal-1/2 & Hal-1/6 & Hal-1/10 & Hal-1/20 \\
\hline Water & $14 \%$ & $14 \%$ & $13 \%$ & $15 \%$ & $15 \%$ \\
\hline TFE 30\% & $32 \%$ & $32 \%$ & $37 \%$ & $36 \%$ & $36 \%$ \\
TFE 50\% & $32 \%$ & $32 \%$ & $40 \%$ & $42 \%$ & $36 \%$ \\
\hline SDS 0.016 mM & $13 \%$ & $13 \%$ & $3 \%$ & $14 \%$ & $14 \%$ \\
SDS 0.16 mM & $14 \%$ & $14 \%$ & $3 \%$ & $18 \%$ & $52 \%$ \\
SDS 2 mM & $46 \%$ & $46 \%$ & $66 \%$ & $63 \%$ & $36 \%$ \\
SDS 4 mM & $51 \%$ & $51 \%$ & $46 \%$ & $63 \%$ & $32 \%$ \\
SDS 8 mM & $37 \%$ & $37 \%$ & $46 \%$ & $50 \%$ & $31 \%$ \\
SDS 16 mM & $31 \%$ & $31 \%$ & $36 \%$ & $36 \%$ & $42 \%$ \\
\hline
\end{tabular}

Table A2. Estimation of the secondary structure content calculated from ECD spectra using the CDPro package [62,73] for HAL-1 and its analogs in aqueous solution, and in the presence of SDS.

\begin{tabular}{|c|c|c|c|c|c|c|c|}
\hline \multirow{2}{*}{ Structure } & \multicolumn{7}{|c|}{ Sodium Dodecyl Sulfate } \\
\hline & $0 \mathrm{mM}$ & $0.016 \mathrm{mM}$ & $0.16 \mathrm{mM}$ & $2 \mathrm{mM}$ & $4 \mathrm{mM}$ & $8 \mathrm{mM}$ & $16 \mathrm{mM}$ \\
\hline $\begin{array}{l}\text { HAL-1 } \\
\alpha \text {-helix }\end{array}$ & $12 \%$ & $12 \%$ & $14 \%$ & $61 \%$ & $61 \%$ & $53 \%$ & $53 \%$ \\
\hline$\beta$-sheet & $50 \%$ & $50 \%$ & $44 \%$ & $6 \%$ & $6 \%$ & $10 \%$ & $10 \%$ \\
\hline$\beta$-turn & $16 \%$ & $16 \%$ & $16 \%$ & $12 \%$ & $12 \%$ & $17 \%$ & $17 \%$ \\
\hline Other & $22 \%$ & $22 \%$ & $26 \%$ & $22 \%$ & $22 \%$ & $21 \%$ & $21 \%$ \\
\hline
\end{tabular}


Table A2. Cont.

\begin{tabular}{|c|c|c|c|c|c|c|c|}
\hline \multicolumn{8}{|l|}{ HAL-1/2 } \\
\hline$\alpha$-helix & $12 \%$ & $11 \%$ & $14 \%$ & $14 \%$ & $47 \%$ & $47 \%$ & $44 \%$ \\
\hline$\beta$-sheet & $53 \%$ & $54 \%$ & $45 \%$ & $44 \%$ & $13 \%$ & $13 \%$ & $15 \%$ \\
\hline$\beta$-turn & $16 \%$ & $16 \%$ & $16 \%$ & $16 \%$ & $18 \%$ & $18 \%$ & $18 \%$ \\
\hline Other & $19 \%$ & $19 \%$ & $25 \%$ & $25 \%$ & $22 \%$ & $22 \%$ & $24 \%$ \\
\hline \multicolumn{8}{|l|}{ HAL-1/6 } \\
\hline$\alpha$-helix & $12 \%$ & $13 \%$ & $11 \%$ & $82 \%$ & $85 \%$ & $70 \%$ & $60 \%$ \\
\hline$\beta$-sheet & $52 \%$ & $42 \%$ & $37 \%$ & $2 \%$ & $2 \%$ & $4 \%$ & $9 \%$ \\
\hline$\beta$-turn & $16 \%$ & $16 \%$ & $14 \%$ & $9 \%$ & $9 \%$ & $14 \%$ & $19 \%$ \\
\hline Other & $20 \%$ & $29 \%$ & $38 \%$ & $6 \%$ & $4 \%$ & $11 \%$ & $14 \%$ \\
\hline \multicolumn{8}{|l|}{ HAL-1/10 } \\
\hline$\alpha$-helix & $11 \%$ & $12 \%$ & $13 \%$ & $80 \%$ & $79 \%$ & $72 \%$ & $70 \%$ \\
\hline$\beta$-sheet & $52 \%$ & $51 \%$ & $43 \%$ & $2 \%$ & $2 \%$ & $4 \%$ & $5 \%$ \\
\hline$\beta$-turn & $16 \%$ & $16 \%$ & $16 \%$ & $10 \%$ & $10 \%$ & $14 \%$ & $15 \%$ \\
\hline Other & $21 \%$ & $21 \%$ & $27 \%$ & $8 \%$ & $9 \%$ & $10 \%$ & $10 \%$ \\
\hline \multicolumn{8}{|l|}{ HAL-1/20 } \\
\hline$\alpha$-helix & $12 \%$ & $13 \%$ & $66 \%$ & $42 \%$ & $39 \%$ & $37 \%$ & $60 \%$ \\
\hline$\beta$-sheet & $52 \%$ & $42 \%$ & $5 \%$ & $13 \%$ & $17 \%$ & $18 \%$ & $18 \%$ \\
\hline$\beta$-turn & $16 \%$ & $13 \%$ & $12 \%$ & $17 \%$ & $18 \%$ & $18 \%$ & $17 \%$ \\
\hline Other & $20 \%$ & $32 \%$ & $18 \%$ & $28 \%$ & $27 \%$ & $27 \%$ & $15 \%$ \\
\hline
\end{tabular}

Table A3. Estimation of the secondary structure content calculated from ECD spectra using the CDPro package $[62,73]$ for HAL-1 and its analogs in aqueous solution, and in the presence of LUVs.

\begin{tabular}{|c|c|c|c|c|c|c|}
\hline \multirow{2}{*}{ Structure } & \multicolumn{6}{|c|}{ LUV } \\
\hline & $0 \mathrm{mM}$ & $\begin{array}{c}P C \\
(L / P=20)\end{array}$ & $\begin{array}{c}P C \\
(\mathrm{~L} / \mathrm{P}=100)\end{array}$ & $\begin{array}{c}\text { PC/PG (4:1) } \\
(\mathrm{L} / \mathrm{P}=20)\end{array}$ & $\begin{array}{c}\text { PC/PG (1:1) } \\
(\mathrm{L} / \mathrm{P}=20)\end{array}$ & $\begin{array}{c}\text { PC/PG (1:4) } \\
(\mathrm{L} / \mathrm{P}=20)\end{array}$ \\
\hline \multicolumn{7}{|l|}{ HAL-1 } \\
\hline$\alpha$-helix & $12 \%$ & $12 \%$ & $18 \%$ & $35 \%$ & $45 \%$ & $61 \%$ \\
\hline$\beta$-sheet & $50 \%$ & $51 \%$ & $38 \%$ & $17 \%$ & $10 \%$ & $7 \%$ \\
\hline$\beta$-turn & $16 \%$ & $16 \%$ & $18 \%$ & $18 \%$ & $17 \%$ & $12 \%$ \\
\hline Other & $22 \%$ & $21 \%$ & $26 \%$ & $30 \%$ & $22 \%$ & $21 \%$ \\
\hline \multicolumn{7}{|l|}{ HAL-1/2 } \\
\hline$\alpha$-helix & $11 \%$ & $11 \%$ & $17 \%$ & $37 \%$ & $47 \%$ & $69 \%$ \\
\hline$\beta$-sheet & $53 \%$ & $53 \%$ & $40 \%$ & $17 \%$ & $10 \%$ & $5 \%$ \\
\hline$\beta$-turn & $16 \%$ & $16 \%$ & $18 \%$ & $17 \%$ & $16 \%$ & $14 \%$ \\
\hline Other & $19 \%$ & $21 \%$ & $25 \%$ & $29 \%$ & $28 \%$ & $13 \%$ \\
\hline \multicolumn{7}{|l|}{ HAL-1/6 } \\
\hline$\alpha$-helix & $12 \%$ & $12 \%$ & $14 \%$ & $60 \%$ & $79 \%$ & $60 \%$ \\
\hline$\beta$-sheet & $52 \%$ & $50 \%$ & $45 \%$ & $7 \%$ & $1 \%$ & $6 \%$ \\
\hline$\beta$-turn & $16 \%$ & $16 \%$ & $17 \%$ & $8 \%$ & $5 \%$ & $12 \%$ \\
\hline Other & $20 \%$ & $22 \%$ & $24 \%$ & $25 \%$ & $14 \%$ & $21 \%$ \\
\hline \multicolumn{7}{|l|}{ HAL-1/10 } \\
\hline$\alpha$-helix & $11 \%$ & $12 \%$ & $13 \%$ & $35 \%$ & $69 \%$ & $36 \%$ \\
\hline$\beta$-sheet & $52 \%$ & $52 \%$ & $51 \%$ & $18 \%$ & $3 \%$ & $38 \%$ \\
\hline$\beta$-turn & $16 \%$ & $16 \%$ & $17 \%$ & $17 \%$ & $9 \%$ & $14 \%$ \\
\hline Other & $21 \%$ & $20 \%$ & $19 \%$ & $30 \%$ & $7 \%$ & $13 \%$ \\
\hline \multicolumn{7}{|l|}{ HAL-1/20 } \\
\hline$\alpha$-helix & $12 \%$ & $12 \%$ & $14 \%$ & $25 \%$ & $80 \%$ & $46 \%$ \\
\hline$\beta$-sheet & $52 \%$ & $50 \%$ & $46 \%$ & $24 \%$ & $2 \%$ & $13 \%$ \\
\hline$\beta$-turn & $16 \%$ & $16 \%$ & $17 \%$ & $18 \%$ & $10 \%$ & $18 \%$ \\
\hline Other & $20 \%$ & $21 \%$ & $22 \%$ & $34 \%$ & $7 \%$ & $24 \%$ \\
\hline
\end{tabular}


Table A4. Estimation of the secondary structure content from IR spectra, using a bandfitting procedure for HAL- 1 and its analogs in aqueous solution $\left(\mathrm{H}_{2} \mathrm{O}\right.$ and $\left.\mathrm{D}_{2} \mathrm{O}\right)$, in the presence of SDS, TFE, and LUVs. The numbers in parentheses correspond to percentages of each fitted band in the amide I region.

\begin{tabular}{|c|c|c|c|c|c|c|c|c|}
\hline \multirow{2}{*}{ Solvent } & \multirow{2}{*}{ Amide $\mathrm{I}\left(\mathrm{cm}^{-1}\right)$} & \multicolumn{7}{|c|}{ Second Derivative Decomposition of Amide I $\left(\mathrm{cm}^{-1}\right)$} \\
\hline & & aggregate & $\beta$-sheet & $\alpha$-helix & $3_{10}$-helix & coil & $\beta$-turn & $\beta$-sheet \\
\hline \multicolumn{9}{|l|}{ HAL-1 } \\
\hline $\mathrm{H}_{2} \mathrm{O}$ & 1646 & - & - & - & - & $1648(88)$ & $1683(12)$ & - \\
\hline $\mathrm{D}_{2} \mathrm{O}$ & 1647 & - & - & - & - & $1642(69)$ & $1667(31)$ & - \\
\hline TFE & 1655 & - & $1633(26)$ & $1656(63)$ & - & - & $1680(11)$ & - \\
\hline $\mathrm{SDS} 8 \mathrm{mM} / \mathrm{H}_{2} \mathrm{O}$ & 1655 & $1621(12)$ & $1635(16)$ & $1656(63)$ & - & - & $1682(9)$ & - \\
\hline $\mathrm{SDS} 8 \mathrm{mM} / \mathrm{D}_{2} \mathrm{O}$ & 1649 & - & - & $1649(95)$ & - & - & $1676(5)$ & - \\
\hline PC & 1656 & $1619(5)$ & - & $1656(63)$ & - & - & $1688(33)$ & - \\
\hline PC/PG 1:1 & 1655 & - & $1634(29)$ & $1656(52)$ & - & - & $1680(19)$ & - \\
\hline PC/PG 1:4 & 1656 & - & $1633(6)$ & $1655(58)$ & - & - & $1678(36)$ & - \\
\hline \multicolumn{9}{|l|}{ HAL-1/2 } \\
\hline $\mathrm{H}_{2} \mathrm{O}$ & 1649 & - & $1637(29)$ & - & - & $1650(56)$ & $1684(14)$ & - \\
\hline $\mathrm{SDS} 8 \mathrm{mM} / \mathrm{H}_{2} \mathrm{O}$ & 1655 & - & 1635(38) & $1657(58)$ & - & - & $1685(4)$ & - \\
\hline $\mathrm{PC}$ & 1657 & - & $1642(32)$ & $1657(32)$ & - & - & $1680(35)$ & - \\
\hline PC/PG 1:1 & 1647 & $1628(34)$ & $1642(28)$ & $1658(24)$ & - & - & $1676(13)$ & - \\
\hline PC/PG 1:4 & 1657 & - & $1632(15)$ & $1656(43)$ & - & - & $1680(41)$ & - \\
\hline \multicolumn{9}{|l|}{ HAL-1/6 } \\
\hline $\mathrm{H}_{2} \mathrm{O}$ & 1646 & - & - & - & - & $1647(92)$ & $1682(8)$ & - \\
\hline $\mathrm{SDS} 8 \mathrm{mM} / \mathrm{H}_{2} \mathrm{O}$ & 1654 & $1629(29)$ & - & $1655(69)$ & - & - & - & 1695 (2) \\
\hline $\mathrm{PC}$ & 1654 & $1621(7)$ & $1639(29)$ & $1657(59)$ & - & - & $1680(5)$ & - \\
\hline PC/PG 1:1 & 1656 & $1626(9)$ & $1642(18)$ & $1657(62)$ & - & - & $1682(11)$ & - \\
\hline \multicolumn{9}{|l|}{ HAL-1/10 } \\
\hline $\mathrm{H}_{2} \mathrm{O}$ & 1647 & - & - & - & - & $1647(82)$ & $1681(18)$ & - \\
\hline PC/PG 1:1 & 1655 & $1625(12)$ & $1640(21)$ & $1657(57)$ & - & - & $1681(10)$ & - \\
\hline PC/PG 1:4 & 1656 & - & - & $1656(80)$ & - & - & $1688(20)$ & - \\
\hline \multicolumn{9}{|l|}{ HAL-1/20 } \\
\hline $\mathrm{H}_{2} \mathrm{O}$ & 1644 & - & $1643(93)$ & - & - & - & $1676(7)$ & - \\
\hline $\mathrm{SDS} 8 \mathrm{mM} / \mathrm{H}_{2} \mathrm{O}$ & 1650 & $1629(9)$ & - & $1653(83)$ & - & - & $1685(9)$ & - \\
\hline PC & 1649 & $1625(36)$ & $1639(13)$ & $1654(28)$ & - & - & $1685(22)$ & - \\
\hline PC/PG 1:1 & 1650 & $1628(29)$ & $1642(16)$ & $1659(49)$ & - & - & $1685(6)$ & - \\
\hline PC/PG 1:4 & 1654 & $1621(19)$ & $1634(14)$ & 1655 (43) & - & - & $1678(24)$ & - \\
\hline
\end{tabular}



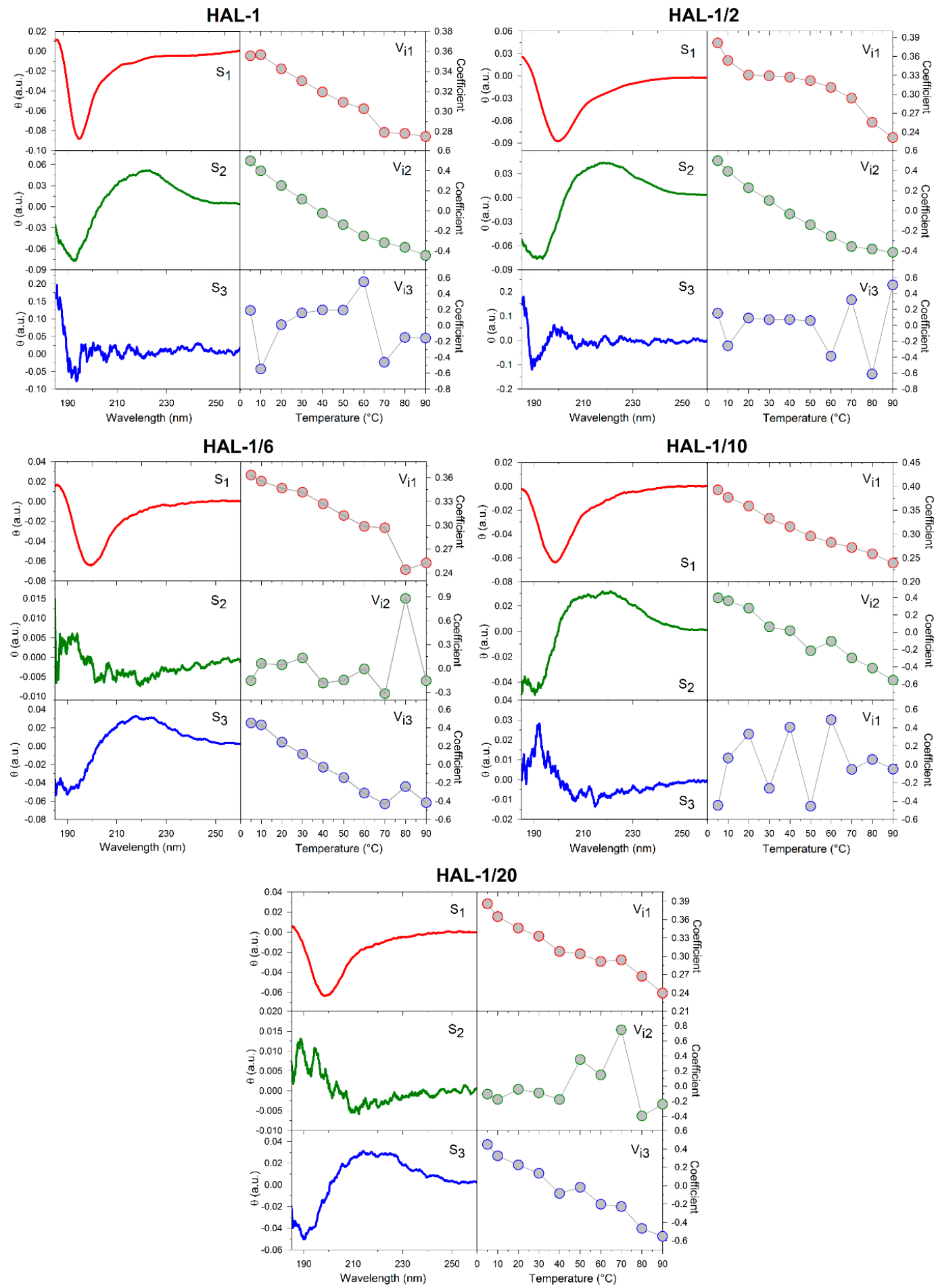

Figure A1. PCA results applied to the set of thermal dependence of ECD spectra (from 5 to $90{ }^{\circ} \mathrm{C}$ ) of HAL- 1 and its analogs. $S_{\mathrm{j}}$ represents the three most significant subspectra, and $V_{\mathrm{ij}}$ represents the appropriate coefficients indicating the relative contribution of the corresponding subspectrum. 
HAL-1

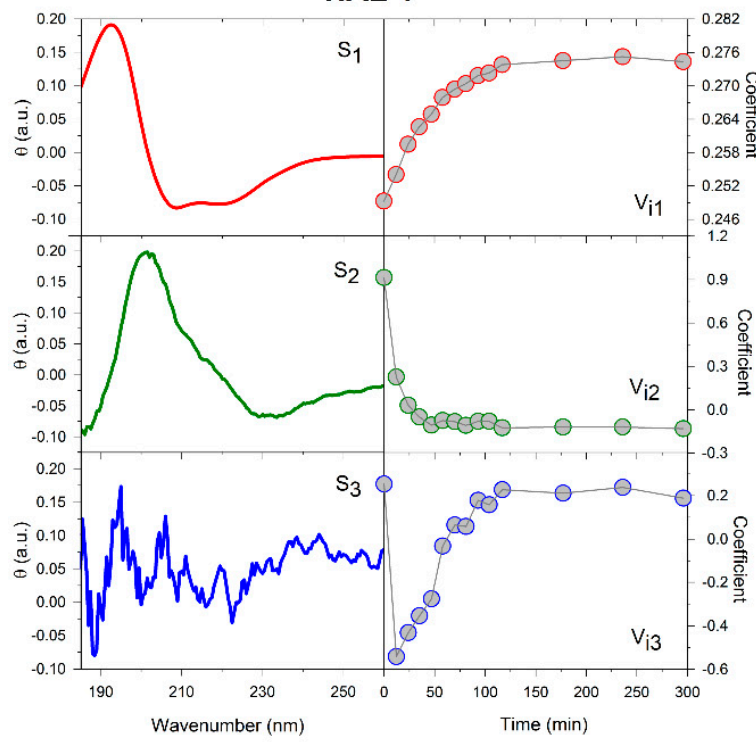

HAL-1/6

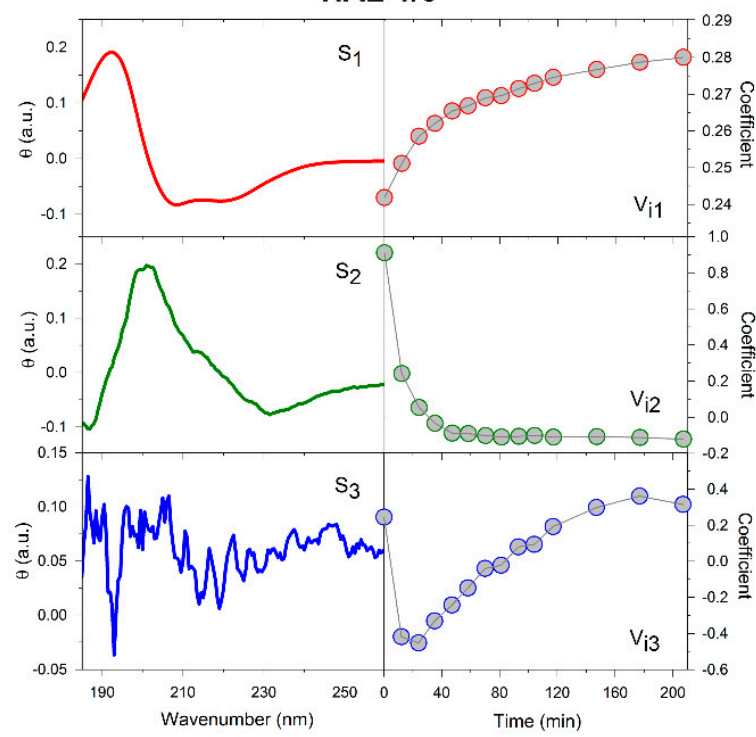

HAL-1/2

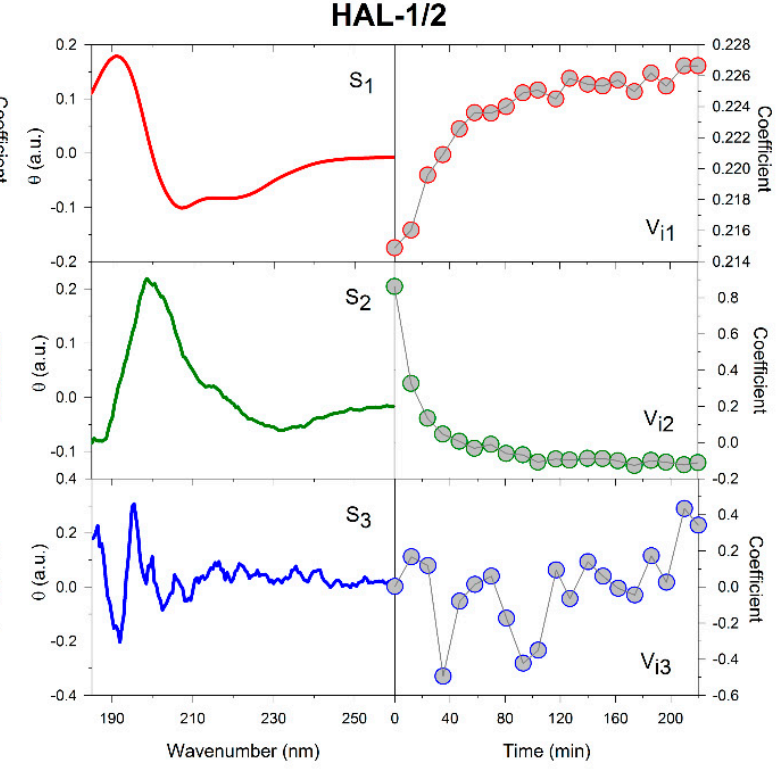

HAL-1/20

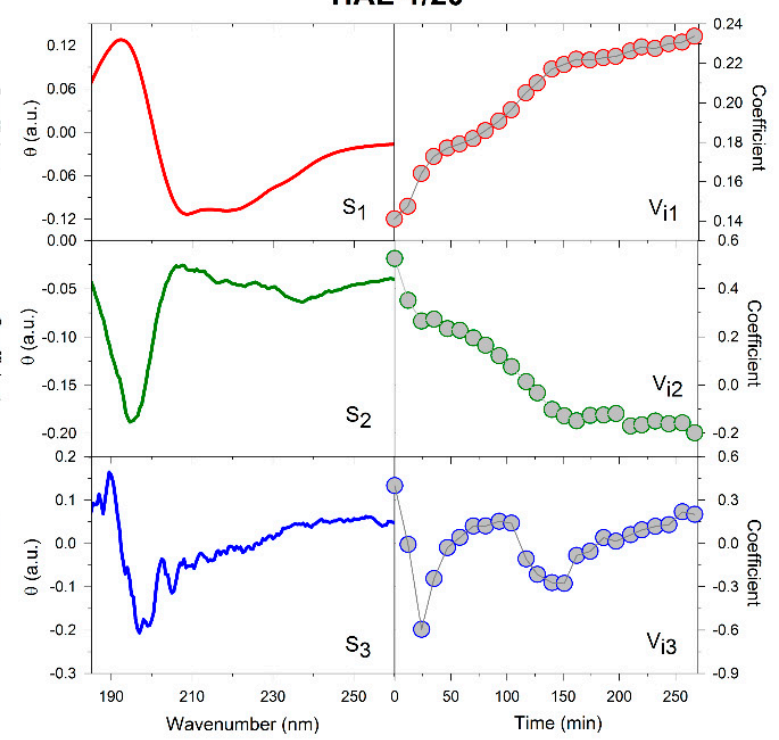

Figure A2. PCA results applied to the set of time dependence of ECD spectra of HAL-1 and its analogs in $P C / P G=1: 4$ mixtures measured within a 220 min time interval after the sample preparation with a 12-min time step. $S_{\mathrm{j}}$ represents the three most significant subspectra and $V_{\mathrm{ij}}$ represents the appropriate coefficients indicating the relative contribution of the corresponding subspectrum.

\section{References}

1. Phoenix, D.A.; Dennison, S.R.; Harris, F. Antibacterial Peptides; Wiley-VCH: Weinheim, Germany, 2013; ISBN 978-3-527-33263-2.

2. Brogden, K.A. Antimicrobial peptides: Pore formers or metabolic inhibitors in bacteria? Nat. Rev. Microbiol. 2005, 3, 238-250. [CrossRef] [PubMed]

3. Fjell, C.D.; Hiss, J.A.; Hancock, R.E.; Schneider, G. Designing antimicrobial peptides: Form follows function. Nat. Rev. Drug Discov. 2012, 11, 37-51. [CrossRef] [PubMed]

4. Zasloff, M. Antimicrobial peptides of multicellular organisms. Nature 2002, 415, 389-395. [CrossRef] [PubMed]

5. Hancock, R.E.; Diamond, G. The role of cationic antimicrobial peptides in innate host defences. Trends Microbiol. 2000, 8, 402-410. [CrossRef] 
6. Hancock, R.E.; Scott, M.G. The role of antimicrobial peptides in animal defenses. Proc. Natl. Acad. Sci. USA 2000, 97, 8856-8861. [CrossRef] [PubMed]

7. Hoskin, D.W.; Ramamoorthy, A. Studies on anticancer activities of antimicrobial peptides. Biochim. Biophys. Acta 2008, 1778, 357-375. [CrossRef] [PubMed]

8. Papo, N.; Shai, Y. Host defense peptides as new weapons in cancer treatment. Cell. Mol. Life Sci. 2005, 62, 784-790. [CrossRef]

9. Papo, N.; Shai, Y. Can we predict biological activity of antimicrobial peptides from their interactions with model phospholipid membranes? Peptides 2003, 24, 1693-1703. [CrossRef]

10. Teixeira, V.; Feio, M.J.; Bastos, M. Role of lipids in the interaction of antimicrobial peptides with membranes. Prog. Lipid Res. 2012, 51, 149-177. [CrossRef]

11. Yount, N.Y.; Yeaman, M.R. Multidimensional signatures in antimicrobial peptides. Proc. Natl. Acad. Sci. USA 2004, 101, 7363-7368. [CrossRef]

12. Epand, R.M.; Epand, R.F. Domains in bacterial membranes and the action of antimicrobial agents. Mol. Biosyst. 2009, 5, 580-587. [CrossRef] [PubMed]

13. Epand, R.M.; Epand, R.F.; Arnusch, C.J.; Papahadjopoulos-Sternberg, B.; Wang, G.; Shai, Y. Lipid clustering by three homologous arginine-rich antimicrobial peptides is insensitive to amino acid arrangement and induced secondary structure. Biochim. Biophys. Acta 2010, 1272-1280. [CrossRef] [PubMed]

14. Wimley, W.C.; Hristova, K. Antimicrobial peptides: Successes, challenges and unanswered questions. J. Membr. Biol. 2011, 239, 27-34. [CrossRef] [PubMed]

15. Blondelle, S.E.; Lohner, K.; Aguilar, M.I. Lipid-induced conformation and lipid-binding properties of cytolytic and antimicrobial peptides: Determination and biological specificity. Biochim. Biophys. Acta 1999, 1462, 89-108. [CrossRef]

16. Epand, R.F.; Mor, A.; Epand, R.M. Lipid complexes with cationic peptides and OAKs; their role in antimicrobial action and in the delivery of antimicrobial agents. Cell. Mol. Life Sci. 2011, 68, 2177-2188. [CrossRef]

17. Čeřovský, V.; Buděšínský, M.; Hovorka, O.; Cvačka, J.; Voburka, Z.; Slaninová, J.; Borovičková, L.; Fučík, V.; Bednárová, L.; Votruba, I.; et al. Lasioglossins: Three novel antimicrobial peptides from the venom of the eusocial bee Lasioglossum laticeps (Hymenoptera: Halictidae). ChemBioChem 2009, 10, 2089-2099. [CrossRef]

18. Čeřovský, V.; Slaninová, J.; Fučík, V.; Monincová, L.; Bednárová, L.; Maloň, P.; Stokrová, J. Lucifensin, a novel insect defensin of medicinal maggots: Synthesis and structural study. ChemBioChem 2011, 12, 1352-1361. [CrossRef]

19. Monincová, L.; Buděšínský, M.; Slaninová, J.; Hovorka, O.; Cvačka, J.; Voburka, Z.; Fučík, V.; Borovičková, L.; Bednárová, L.; Straka, J.; et al. Novel antimicrobial peptides from the venom of the eusocial bee Halictus sexcinctus (Hymenoptera: Halictidae) and their analogs. Amino Acids 2010, 39, 763-775. [CrossRef]

20. Čujová, S.; Bednárová, L.; Slaninová, J.; Straka, J.; Čeřovský, V. Interaction of a novel antimicrobial peptide isolated from the venom of solitary bee Colletes daviesanus with phospholipid vesicles and Escherichia coli cells. J. Pept. Sci. 2014, 20, 885-895. [CrossRef]

21. Stanchev, S.; Zawada, Z.; Monincová, L.; Bednárová, L.; Slaninová, J.; Fučík, V.; Čeřovský, V. Synthesis of lucifensin by native chemical ligation and characteristics of its isomer having different disulfide bridge pattern. J. Pept. Sci. 2014, 20, 725-735. [CrossRef]

22. Nešuta, O.; Hexnerová, R.; Buděšínský, M.; Slaninová, J.; Bednárová, L.; Hadravová, R.; Straka, J.; Veverka, V.; Čeřovský, V. Antimicrobial peptide from the wild bee Hylaeus signatus venom and its analogues: Structure-activity study and synergistic effect with antibiotics. J. Nat. Prod. 2016, 79, 1073-1083. [CrossRef] [PubMed]

23. Pazderková, M.; Kočišová, E.; Pazderka, T.; Maloň, P.; Kopecký, V.; Monincová, L.; Čeřovský, V.; Bednárová, L. Antimicrobial peptide from the eusocial bee Halictus sexcinctus interacting with model membranes. In Advances in Biomedical Spectroscopy; Marques, M.P., Batista de Carvalho, L.A.E., Haris, P.I., Eds.; IOE Press: Amsterdam, The Netherlands, 2013; Volume 7, pp. 79-83. ISBN 978-1-61499-183-0.

24. Myers, J.K.; Pace, C.N.; Scholtz, J.M. Trifluoroethanol effects on helix propensity and electrostatic interactions in the helical peptide from ribonuclease T-1. Protein Sci. 1998, 7, 383-388. [CrossRef] [PubMed]

25. Warschawski, D.E.; Arnold, A.A.; Beaugrand, M.; Gravel, A.; Chartrand, É.; Marcotte, I. Choosing membrane mimetics for NMR structural studies of transmembrane proteins. Biochim. Biophys. Acta 2011, 1808, 1957-1974. [CrossRef] [PubMed] 
26. Strandberg, E.; Tiltak, D.; Ehni, S.; Wadhwani, P.; Ulrich, A.S. Lipid shape is a key factor for membrane interactions of amphipathic helical peptides. Biochim. Biophys. Acta 2012, 1818, 1764-1776. [CrossRef]

27. Eisenberg, D.; Weiss, R.M.; Terwilliger, T.C. The helical hydrophobic moment: A measure of the amphiphilicity of a helix. Nature 1982, 277, 371-374. [CrossRef]

28. Thévenet, P.; Shen, Y.; Maupetit, J.; Guyon, F.; Derreumaux, P.; Tufféry, P. PEP-FOLD: An updated de novo structure prediction server for both linear and disulfide bonded cyclic peptides. Nucleic Acids Res. 2012, 40, W288-W293. [CrossRef] [PubMed]

29. Sreerama, N.; Woody, R.W. Estimation of protein secondary structure from circular dichroism spectra: Comparison of CONTIN, SELCON, and CDSSTR methods with an expanded reference set. Anal. Biochem. 2000, 287, 252-260. [CrossRef] [PubMed]

30. Backlund, B.; Wikander, G.; Peeters, T.L.; Gräslund, A. Induction of secondary structure in the peptide hormone motilin by interaction with phospholipid vesicles. Biochim. Biophys. Acta 1994, 1190, 337-344. [CrossRef]

31. Drake, A.F.; Siligardi, G.; Gibbons, W.A. Reassessment of the electronic circular dichroism criteria for random coil conformations of poly(L-lysine) and the implications for protein folding and denaturation studies. Biophys. Chem. 1988, 31, 143-146. [CrossRef]

32. Wimmer, R.; Andersen, K.K.; Vad, B.; Davidsen, M.; Mølgaard, S.; Nesgaard, L.W.; Kristensen, H.H.; Otzen, D.E. Versatile interactions of the antimicrobial peptide Novispirin with detergents and lipids. Biochemistry 2006, 45, 481-497. [CrossRef] [PubMed]

33. Seddon, A.M.; Curnow, P.; Booth, P.J. Membrane proteins, lipids and detergents: Not just a soap opera. Biochim. Biophys. Acta 2004, 1666, 105-117. [CrossRef] [PubMed]

34. Berova, N.; Polavarapu, P.L.; Nakanishi, K.; Woody, R.W. Comprehensive Chiroptical Spectroscopy Applications in Stereochemical Analysis of Synthetic Compounds, Natural Products and Biomolecules; John Wiley \& Sons: Hoboken, NJ, USA, 2012; ISBN 978-1-118-01292-5.

35. Abdul-Gader, A.; Miles, A.J.; Wallace, B.A. A reference dataset for the analyses of membrane protein secondary structures and transmembrane residues using circular dichroism spectroscopy. Bioinformatics 2011, 27, 1630-1636. [CrossRef] [PubMed]

36. Sreerama, N.; Woody, R.W. Poly(Pro)II helices in globular proteins: Identification and circular dichroic analysis. Biochemistry 1994, 33, 10022-10025. [CrossRef] [PubMed]

37. Whitmore, L.; Woollett, B.; Miles, A.J.; Janes, R.W.; Wallace, B.A. The protein circular dichroism data bank, a Web-based site for access to circular dichroism spectroscopic data. Structure 2010, 18, 1267-1269. [CrossRef] [PubMed]

38. Johnson, W.C. Analyzing protein circular dichroism spectra for accurate secondary structures. Proteins 1999, 35, 307-312. [CrossRef]

39. Bochicchio, B.; Tamburro, A.M. Polyproline II structure in proteins: Identification by chiroptical spectroscopies, stability, and functions. Chirality 2002, 14, 782-792. [CrossRef] [PubMed]

40. Lopes, J.L.S.; Miles, A.J.; Whitmore, L.; Wallace, B.A. Distinct circular dichroism spectroscopic signatures of polyproline II and unordered secondary structures: Applications in secondary structure analyses. Protein Sci. 2014, 23, 1765-1772. [CrossRef] [PubMed]

41. Barth, A. Infrared spectroscopy of proteins. Biochim. Biophys. Acta 2007, 1767, 1073-1101. [CrossRef]

42. Yang, H.; Yang, S.; Kong, J.; Dong, A.; Yu, S. Obtaining information about protein secondary structures in aqueous solution using Fourier transform IR spectroscopy. Nat. Protoc. 2015, 10, 382-396. [CrossRef]

43. Tesař, A.; Kopecký Jr., V.; Kočišová, E.; Bednárová, L. Dynamics of lipid layers with/without bounded antimicrobial peptide halictine-1. Vibrat. Spectrosc. 2017, 93, 42-51. [CrossRef]

44. Miller, L.M.; Bourassa, M.W.; Smith, R.J. FTIR spectroscopic imaging of protein aggregation in living cells. Biochim. Biophys. Acta 2013, 1828, 2339-2346. [CrossRef] [PubMed]

45. Jackson, M.; Mantsch, H.H. The use and misuse of FTIR spectroscopy in the determination of protein structure. Crit. Rev. Biochem. Mol. Biol. 1995, 30, 95-120. [CrossRef] [PubMed]

46. Keiderling, T.A.; Silva, R.A.; Yoder, G.; Dukor, R.K. Vibrational circular dichroism spectroscopy of selected oligopeptide conformations. Bioorg. Med. Chem. 1999, 7, 133-141. [CrossRef]

47. Keiderling, T.A. Protein and peptide secondary structure and conformational determination with vibrational circular dichroism. Curr. Opin. Chem. Biol. 2002, 6, 682-688. [CrossRef] 
48. Ma, S.; Freedman, T.B.; Dukor, R.K.; Nafie, L.A. Near-infrared and mid-infrared Fourier transform vibrational circular dichroism of proteins in aqueous solution. Appl. Spectrosc. 2010, 64, 615-626. [CrossRef] [PubMed]

49. Ma, S.; Cao, X.; Mak, M.; Sadik, A.; Walkner, C.; Freedman, T.B.; Lednev, I.K.; Dukor, R.K.; Nafie, L.A. Vibrational circular dichroism shows unusual sensitivity to protein fibril formation and development in solution. J. Am. Chem. Soc. 2007, 129, 12364-12365. [CrossRef] [PubMed]

50. Kurouski, D.; Lombardi, R.A.; Dukor, R.K.; Lednev, I.K.; Nafie, L.A. Direct observation and pH control of reversed supramolecular chirality in insulin fibrils by vibrational circular dichroism. Chem. Commun. 2010, 46, 7154-7156. [CrossRef] [PubMed]

51. Measey, T.J.; Schweitzer-Stenner, R. Vibrational circular dichroism as a probe of fibrillogenesis: The origin of the anomalous intensity enhancement of amyloid-like fibrils. J. Am. Chem. Soc. 2011, 133, 1066-1076. [CrossRef]

52. Krishnakumar, S.S.; London, E. Effect of sequence hydrophobicity and bilayer width upon the minimum length required for the formation of transmembrane helices in membranes. J. Mol. Biol. 2007, 374, 671-687. [CrossRef]

53. Zeth, K. Structure and mechanism of human antimicrobial peptide dermcidin and its antimicrobial potential. In Microbial Pathogens and Strategies for Combating Them: Science, Technology and Education; Méndez-Vilas, A., Ed.; Formatex Research Center: Badajoz, Spain, 2013; Volume 2, pp. 1333-1342. ISBN 978-84-942134-0-3.

54. Huang, H.W. Molecular mechanism of antimicrobial peptides: The origin of cooperativity. Biochim. Biophys. Acta 2006, 1758, 1292-1302. [CrossRef]

55. Millhauser, G.L. Views of helical peptides: A proposal for the position of 310 -helix along the thermodynamic folding pathway. Biochemistry 1995, 34, 3873-3877. [CrossRef] [PubMed]

56. Leontiadou, H.; Mark, A.E.; Marrink, S.J. Antimicrobial peptides in action. J. Am. Chem. Soc. 2006, 128, 12156-12161. [CrossRef] [PubMed]

57. Forbrig, E.; Staffa, J.K.; Salewski, J.; Mroginski, M.A.; Hildebrandt, P.; Kozuch, J. Monitoring the orientational changes of Alamethicin during incorporation into bilayer lipid membranes. Langmuir 2018, 34, 2373-2385. [CrossRef] [PubMed]

58. Reißer, S.; Strandberg, E.; Steinbrecher, T.; Elstner, M.; Ulrich, A.S. Best of two worlds? How MD simulations of amphiphilic helical peptides in membranes can complement data from oriented solid-state NMR. J. Chem. Theory Comput. 2018, 14, 6002-6014. [CrossRef] [PubMed]

59. Andruschenko, V.; Vogel, H.J.; Prenner, E.J. Optimization of the hydrochloric acid concentration used for trifluoroacetate removal from synthetic peptides. J. Pept. Sci. 2007, 13, 37-43. [CrossRef] [PubMed]

60. Mukerjee, P.; Mysels, K.J. Critical Micelle Concentration of Aqueous Surfactant Systems; NSRDS-NBS 36; U.S. Department of Commerce: Washington, DC, USA, 1971.

61. Rohl, C.; Baldwin, R.L. Deciphering rules of helix stability in peptides. Methods Enzymol. 1998, $296,1-26$. [CrossRef]

62. Sreerama, N.; Woody, R.W. Computation and analysis of protein circular dichroism spectra. Methods Enzymol. 2004, 383, 318-351. [CrossRef]

63. Malinowski, E.R. Factor Analysis in Chemistry, 3rd ed.; Wiley: Chichester, UK, 2002; ISBN 0-471-13479-1.

64. Dousseau, F.; Therrien, M.; Pézolet, M. On the spectral subtraction of water from the FT-IR spectra of aqueous solutions of proteins. Appl. Spectrosc. 1989, 43, 538-542. [CrossRef]

65. Roux, S.; Zékri, E.; Rousseau, B.; Paternostre, M.; Cintrat, J.C.; Fay, N. Elimination and exchange of trifluoroacetate counter-ion from cationic peptides: A critical evaluation of different approaches. J. Pept. Sci. 2008, 14, 354-359. [CrossRef]

66. Nafie, L.A.; Buijs, H.; Rilling, A.; Cao, X.; Dukor, R.K. Dual source Fourier transform polarization modulation spectroscopy: An improved method for the measurement of circular and linear dichroism. Appl. Spectrosc. 2004, 58, 647-654. [CrossRef]

67. Nafie, L.A. Dual polarization modulation: Real-time, spectral multiplex separation of circular dichroism from linear birefringence spectral intensities. Appl. Spectrosc. 2000, 54, 1634-1645. [CrossRef]

68. Case, D.A.; Darden, T.A.; Cheatham, T.E., III; Simmerling, C.L.; Wang, J.; Duke, R.E.; Luo, R.; Walker, R.C.; Zhang, W.; Merz, K.M.; et al. AMBER 11; University of California: San Francisco, CA, USA, 2010. 
69. Hornak, V.; Abel, R.; Okur, A.; Strockbine, B.; Roitberg, A.; Simmerling, C. Comparison of multiple Amber force fields and development of improved protein backbone parameters. Proteins 2006, 65, 712-725. [CrossRef] [PubMed]

70. Humphrey, W.; Dalke, A.; Schulten, K. VMD: Visual Molecular Dynamics. J. Mol. Graph. 1996, 14, $33-38$. [CrossRef]

71. Phillips, J.C.; Braun, R.; Wang, W.; Gumbart, J.; Tajkhorshid, E.; Villa, E.; Chipot, C.; Skeel, R.D.; Kalé, L.; Schulten, K. Scalable molecular dynamics with NAMD. J. Comput. Chem. 2005, 26, 1781-1802. [CrossRef] [PubMed]

72. Miyamoto, S.; Kollman, P.A.; Settle, K. An analytical version of the SHAKE and RATTLE algorithm for rigid water models. J. Comput. Chem. 1992, 13, 952-962. [CrossRef]

73. Sreerama, N.; Woody, R.W. On the analysis of membrane protein circular dichroism spectra. Protein Sci. 2004, 13, 100-112. [CrossRef] [PubMed]

(C) 2019 by the authors. Licensee MDPI, Basel, Switzerland. This article is an open access article distributed under the terms and conditions of the Creative Commons Attribution (CC BY) license (http://creativecommons.org/licenses/by/4.0/). 